\title{
Review
}

\section{Transition metal-nitrogen sites for electrochemical carbon dioxide reduction reaction}

\author{
Chengcheng Yan ${ }^{\mathrm{a}, \mathrm{b}}$, Long Lin ${ }^{\mathrm{a}, \mathrm{b}}$, Guoxiong Wang a,c,*, Xinhe Bao a,c,\# \\ a State Key Laboratory of Catalysis, CAS Center for Excellence in Nanoscience, Dalian Institute of Chemical Physics, Chinese Academy of Sciences, Dalian \\ 116023, Liaoning, China \\ b University of Chinese Academy of Sciences, Beijing 100049, China \\ c Dalian National Laboratory for Clean Energy, Dalian Institute of Chemical Physics, Chinese Academy of Sciences, Dalian 116023, Liaoning, China
}

\section{A R T I C L E I N F O}

\section{Article history:}

Received 4 September 2018

Accepted 19 September 2018

Published 5 January 2019

\section{Keywords:}

Electrochemical carbon dioxide

reduction reaction

Metal-nitrogen sites

Metal-nitrogen containing

macrocyclic complexes

Metal organic frameworks

Zeolitic imidazolate frameworks

Carbon material doped with

metal-nitrogen sites

\begin{abstract}
A B S T R A C T
Electrochemical $\mathrm{CO}_{2}$ reduction reaction $\left(\mathrm{CO}_{2} \mathrm{RR}\right)$ powered by renewable electricity has emerged as the most promising technique for $\mathrm{CO}_{2}$ conversion, making it possible to realize a carbon-neutral cycle. Highly efficient, robust, and cost-effective catalysts are highly demanded for the near-future practical applications of $\mathrm{CO}_{2} \mathrm{RR}$. Previous studies on atomically dispersed metal-nitrogen (M- $\left.\mathrm{N}_{x}\right)$ sites constituted of earth abundant elements with maximum atom-utilization efficiency have demonstrated their performance towards $\mathrm{CO}_{2} \mathrm{RR}$. This review summarizes recent advances on a variety of $\mathrm{M}-\mathrm{N}_{x}$ sites-containing transition metal-centered macrocyclic complexes, metal organic frameworks, and $\mathrm{M}-\mathrm{N}_{x}$-doped carbon materials for efficient $\mathrm{CO}_{2} \mathrm{RR}$, including both experimental and theoretical studies. The roles of metal centers, coordinated ligands, and conductive supports on the intrinsic activity and selectivity, together with the importance of reaction conditions for improved performance are discussed. The mechanisms of $\mathrm{CO}_{2} \mathrm{RR}$ over these $\mathrm{M}-\mathrm{N}_{x}$-containing materials are presented to provide useful guidance for the rational design of efficient catalysts towards $\mathrm{CO}_{2} \mathrm{RR}$.
\end{abstract}

(C) 2019, Dalian Institute of Chemical Physics, Chinese Academy of Sciences. Published by Elsevier B.V. All rights reserved.

\section{Introduction}

The rapid consumption of fossil fuels, together with continuously increasing population and over exploitation of forests, is the major culprit for the high atmospheric $\mathrm{CO}_{2}$ level. Excessive $\mathrm{CO}_{2}$ concentration will exacerbate the greenhouse effect, causing average temperature to rise and posing great challenges to global climate and environment [1]. Though notorious, $\mathrm{CO}_{2}$ is also a potential carbon resource [2-4]. Electrochemical $\mathrm{CO}_{2}$ reduction reaction $\left(\mathrm{CO}_{2} \mathrm{RR}\right)$ is a promising technique for efficient $\mathrm{CO}_{2}$ conversion. $\mathrm{CO}_{2} \mathrm{RR}$ technique can utilize electricity generated by clean renewable energy and directly convert $\mathrm{CO}_{2}$ into value-added chemicals ( $\mathrm{CO}$, formate, hydrocarbon, oxygenated compounds, etc.), making it possible to realize an ideal recycling cycle for carbon resources [5-8]. However, the undesirable energy conversion efficiency caused by a high overpotential in initiating $\mathrm{CO}_{2}$ conversion and limited selectivity due to the competitive hydrogen evolution reaction (HER) in aque-

\footnotetext{
* Corresponding author. Tel: +86-411-84686637; Fax: +86-411-84694447; E-mail: wanggx@dicp.ac.cn

\# Corresponding author. E-mail: xhbao@dicp.ac.cn

This work was supported by the National Key R\&D Program of China (2017YFA0700102), the National Natural Science Foundation of China (21573222 and 91545202), the Outstanding Youth Talent Project of Dalian (2017RJ03), the DMTO Project of Dalian Institute of Chemical Physics, CAS (DICP DMT0201702), the Strategic Priority Research Program of the Chinese Academy of Sciences (XDB17020200), and the Youth Innovation Promotion Association, CAS (2015145).
}

DOI: 10.1016/S1872-2067(18)63161-4 | http://www.sciencedirect.com/science/journal/18722067| Chin. J. Catal., Vol. 40, No. 1, January 2019 
ous solution discourage the near-future practical applications of $\mathrm{CO}_{2} \mathrm{RR}$ [9-12]. Therefore, intensive research work has been focused on developing highly efficient catalysts. From early well-studied bulk metal catalysts to recent widespread metallic nanostructure/nanomaterials, researchers have done intense work on the investigation of structure-activity relationship towards $\mathrm{CO}_{2} \mathrm{RR}$ through constructing active nanostructure for more exposed active sites, modulating nanoparticle size and active facet ratio, introducing second alloy constituent, utilizing metal-oxide interface confinement effect, etc., to optimize the catalytic performance and further confirm that the binding energy and structure of absorbed intermediates are crucial for high selectivity [13-20]. At present, $\mathrm{Au}$-, Ag-, Pd- and Cu-based catalysts have been widely investigated for $\mathrm{CO}_{2} \mathrm{RR}$ and exhibit considerable Faradaic efficiencies, yet the low mass activity and scarcity of these noble metal catalysts impede their future applications [9,21-24]. Alternatively, catalysts containing transition metal-nitrogen $\left(\mathrm{M}-\mathrm{N}_{x}\right)$ sites, such as transition metal-centered macrocyclic complexes, metal organic frameworks and $\mathrm{M}-\mathrm{N}_{x}$-doped carbon materials, which show comparable or even higher activity and selectivity towards $\mathrm{CO}_{2} \mathrm{RR}$ than noble metal counterparts, are emerging as promising candidates [25-27]. In particular, low-cost $\mathrm{M}-\mathrm{N}_{x}$-doped carbon materials synthesized by a facile pyrolysis of precursors containing $\mathrm{N}, \mathrm{C}$ and transition metal elements, which have been widely explored as the most promising alternatives for noble metal-based catalysts in polymer electrolyte membrane fuel cells [28-30], have shown remarkable activity and selectivity towards $\mathrm{CO}_{2} \mathrm{RR}$ and triggered a wave of research in recent years [11,31-33]. This review summarizes recent advances on the $\mathrm{CO}_{2} \mathrm{RR}$ using a variety of $\mathrm{M}-\mathrm{N}_{x}$-containing materials, and practical parameters, such as synthesis protocols, characterization of active sites, and electrocatalytic performance evaluation are included, while we also discuss about the proposed reaction mechanisms and major factors that affect product distribution. We expect this review will provide practical knowledge into the rational design of improved $\mathrm{M}-\mathrm{N}_{x}$-containing catalysts and exploration of optimal process conditions, which are crucial in promoting the practical application of $\mathrm{CO}_{2} \mathrm{RR}$ in the near future.

\section{Metal-nitrogen containing macrocyclic complexes}

Transition metal-centered macrocyclic complexes, either in solution (homogeneous catalysis) or anchored to carbon materials/electrode (heterogeneous catalysis), have been explored as efficient catalysts for $\mathrm{CO}_{2} \mathrm{RR}$ since the 1970s. In particular, metal porphyrins, phthalocyanines and their relative derivatives (Fig. 1) have been widely studied. Examination of product selectivity on gas diffusion electrodes (GDE) impregnated with 17 kinds of metal phthalocyanines by Matsui et al. [34] showed that with transition metals of Group VIII as the coordination center, $\mathrm{CO}$ was produced as the major electrolysis product and the Faradaic efficiency on $\mathrm{Co}$ and $\mathrm{Ni}$ phthalocyanines almost reached $100 \%$; in the case of $\mathrm{Sn}, \mathrm{Pb}$ or In (Group IIIA or IVA) phthalocyanines, formic acid was the major product; while methane was produced mainly on $\mathrm{Ga}, \mathrm{Cu}$ and $\mathrm{Ti}$ phthalocyanines, with the highest Faradaic efficiencies of 30\%-40\%. Followed up the research work, Furuya et al. [35] interpreted such discriminative difference qualitatively by Taube's theory, i.e. the electron configurations in the metallic atom affected $\mathrm{CO}_{2}$ activation and CO desorption, consistent with that proposed by Meshitsuka et al.. Based on earlier studies, more efficient macrocyclic complexes with varying metal centers (mainly $\mathrm{Co}, \mathrm{Fe}$, $\mathrm{Mn}$ and $\mathrm{Zn}$ ) and tailorable ligands are developed by structural engineering at the molecular level or constructing hybrid architecture at the nanoscopic scale [36-43].

At the potentials required for $\mathrm{CO}_{2} \mathrm{RR}$, the metal centers of metal phthalocyanines or other macrocyclic complexes are prone to be reduced to a low oxidation state while the macrocyclic ligand framework contributes to maintain chemical stability and store a proton and/or a reducing equivalent. Thus the intrinsic structure of active sites has been controversial all the time and intense efforts have been made to detect reaction intermediates and theoretical protocols are used to shed light on the reaction mechanisms. Savéant et al. [39,44] have done much work on improving the performance of iron tetraphenylporphyrin (FeTPP) derived molecular catalysts. Cyclic voltammetry results of the redox process of Fe oxidation state with variation of potential revealed that electrogenerated iron(0) porphyrins are active sites for $\mathrm{CO}_{2} \mathrm{RR}$ and prepositioned phenol functionalities help improve the activity by acting as both H-bonding stabilizers and high-concentration proton donors (Fig. 2). Similarly, experimental and theoretical studies confirmed that Co center is first reduced to $\operatorname{Co}(\mathrm{I})$ and then $\mathrm{CO}_{2}$ is adsorbed and further reduced to $\mathrm{CO}[41,42,45,46]$. In a recent study, Wang et al. [47] discovered that a $\mathrm{Cu}$ phthal-
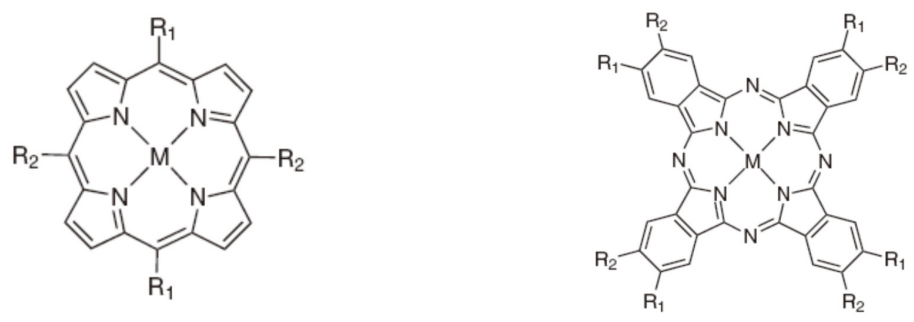

$\mathrm{R}_{1}=\mathrm{R}_{2}=\mathrm{H}$, Metal porphyrin, Mpor

$\mathrm{R}_{1}=\mathrm{R}_{2}=\mathrm{C}_{6} \mathrm{H}_{5}$, Metal tetraphenylporphyrin, MTPP

$\mathrm{R}_{1}=\mathrm{R}_{2}=\mathrm{H}$ Metal phthalocyanine, MPc

$\mathbf{R}_{1}=R_{2}=C N$ Metal nitrile phthalocyanine, $\operatorname{MPc}(\mathrm{CN})_{8}$

$\mathrm{R}_{1}=\mathrm{R}_{2}=\mathrm{C}_{6} \mathrm{~F}_{5}$, Metal tetrakis(pentafluorophenyl)porphyrin, MTPFPP $\mathrm{R}_{1}=\mathrm{R}_{2}=\mathrm{NH}_{2}$ Metal tetraamino phthalocyanine, MTAPc

Fig. 1. Commonly used metal porphyrins, phthalocyanines and derivatives for $\mathrm{CO}_{2} \mathrm{RR}$. 
(a)

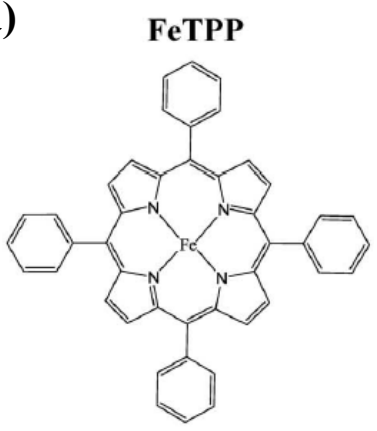

(b)

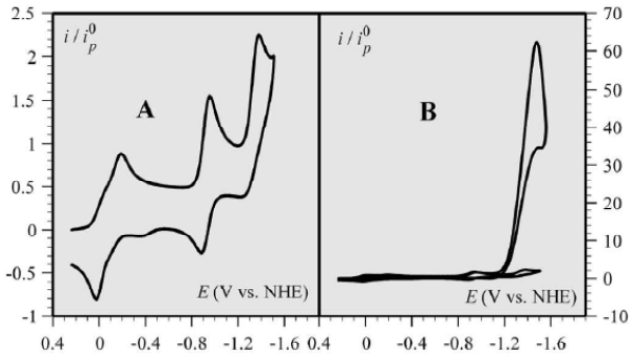

FeTDHPP

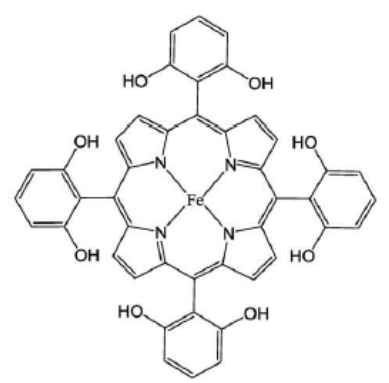

FeTDMPP

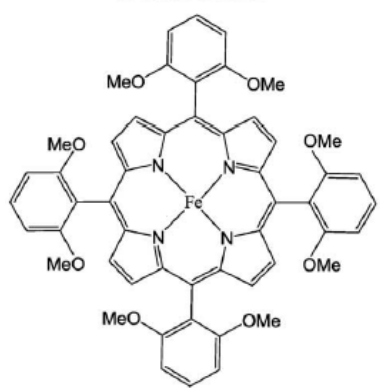

(c)

$$
\begin{aligned}
& {[(\text { por }) \mathrm{Fe}(\mathrm{I})]^{-}+\mathrm{e}^{-} \rightleftharpoons[(\text { por }) \mathrm{Fe}(0)]^{2-}} \\
& {[(\text { por }) \mathrm{Fe}(0)]^{2-}+\mathrm{CO}_{2}+2 \mathrm{AH} \stackrel{k}{\longrightarrow}[(\text { por }) \mathrm{Fe}(\mathrm{II}) \mathrm{CO}]+\mathrm{H}_{2} \mathrm{O}+2 \mathrm{~A}^{-}} \\
& {[(\text {por }) \mathrm{Fe}(\mathrm{II}) \mathrm{CO}]+[(\text { por }) \mathrm{Fe}(0)]^{2-} \stackrel{k^{\prime}>>k}{\longrightarrow} \quad 2[(\text { por }) \mathrm{Fe}(\mathrm{I})]^{-}+\mathrm{CO}} \\
& \mathrm{CO}_{2}+2 \mathrm{AH}+2 \mathrm{e}^{-} \longrightarrow \mathrm{CO}+\mathrm{H}_{2} \mathrm{O}+2 \mathrm{~A}^{-} \\
& \text {if } p K_{\left(\mathrm{CO}_{2}+\mathrm{H}_{2} \mathrm{O}\right)} \ll p K_{\mathrm{AH}} \text { : } \\
& \begin{array}{l}
2 \mathrm{~A}^{-}+2\left(\mathrm{CO}_{2}+\mathrm{H}_{2} \mathrm{O}\right) \longrightarrow 2 \mathrm{AH}+2 \mathrm{CO}_{3} \mathrm{H}^{-} \\
3 \mathrm{CO}_{2}+\mathrm{H}_{2} \mathrm{O}+2 \mathrm{e}^{-} \longrightarrow \mathrm{CO}+2 \mathrm{CO}_{3} \mathrm{H}^{-}
\end{array}
\end{aligned}
$$

Fig. 2. (a) Investigated iron porphyrins for $\mathrm{CO}_{2} \mathrm{RR}$; (b) Cyclic voltammetric curves of (A) FeTDHPP $+2 \mathrm{~mol} \mathrm{~L}^{-1} \mathrm{H}_{2} \mathrm{O}$, (B) FeTDHPP $+2 \mathrm{~mol} \mathrm{~L}^{-1} \mathrm{H}_{2} \mathrm{O}$ in the presence (upper trace) and absence (lower trace) of $0.23 \mathrm{~mol} \mathrm{~L}^{-1} \mathrm{CO}_{2}$ in DMF $+0.1 \mathrm{~mol} \mathrm{~L}^{-1} n-\mathrm{Bu}_{4} \mathrm{NPF}_{6}$ electrolyte at $0.1 \mathrm{~V} \mathrm{~s}^{-1}$; (c) Proposed reaction pathway for $\mathrm{CO}_{2} \mathrm{RR}$ by active iron(0) porphyrins site. Reproduced with permission [39]. Copyright 2012, The American Association for the Advancement of Science.

ocyanine based heterogeneous catalyst efficiently converts $\mathrm{CO}_{2}$ to methane and ethylene. Interestingly, in-situ and operando X-ray absorption spectroscopy (XAS) results in Fig. 3 revealed that $\sim 2 \mathrm{~nm}$ metallic copper clusters formed through the reversible oxidation state and structural changes of copper(II) phthalocyanine serving as active centers for the production of methane.

Besides the metal center, the ligands are also crucial to improve the $\mathrm{CO}_{2} \mathrm{RR}$ performance. Costentin et al. [39] found that the high local concentration of protons derived from all the (a)

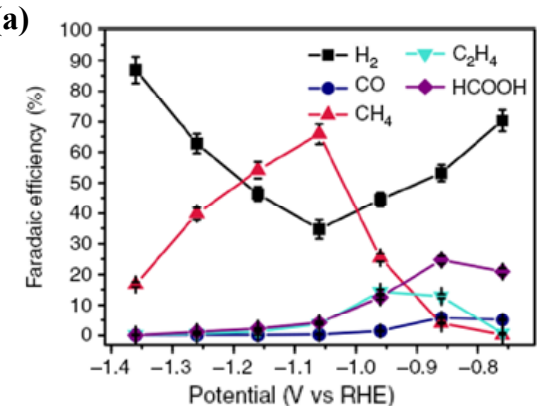

(c)

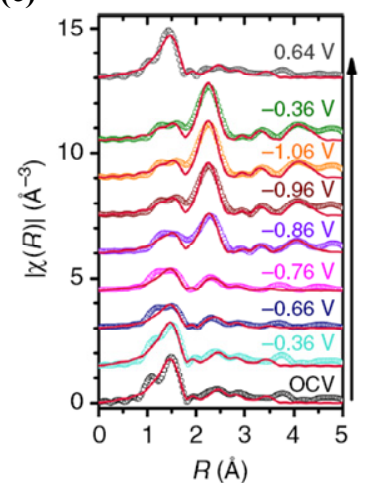

(d)

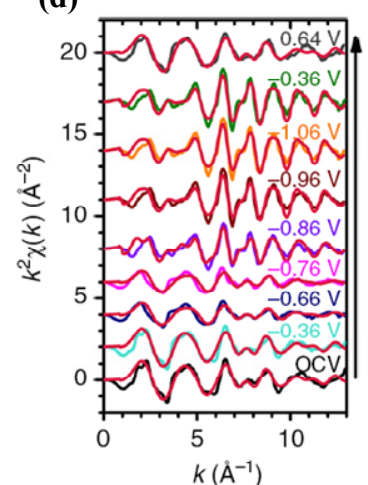

(b)

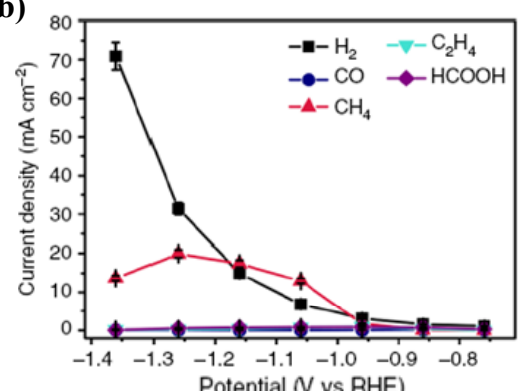

(e)

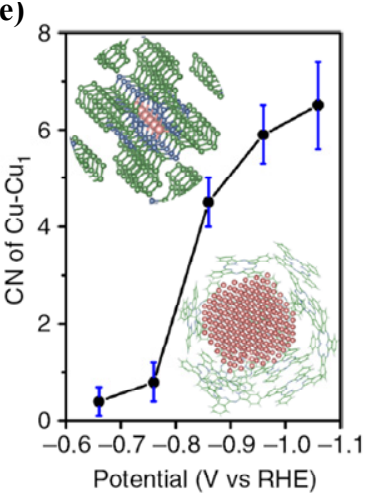

Fig. 3. (a) Potential-dependent Faradaic efficiency and (b) partial current densities of products towards $\mathrm{CO}_{2} \mathrm{RR}$ catalyzed by CuPc; (c) Fitting results (red traces) of the extended X-ray absorption fine structure (EXAFS) spectra of the CuPc at different potentials in $R$ space and (d) $k$-space; (e) First-shell $\mathrm{Cu}-\mathrm{Cu} \mathrm{CNs}$ of the CuPc at different potentials. The insets show the CuPc crystal structure (upper left) and a possible configuration of the $\mathrm{Cu}$ nanoclusters (lower right). Reproduced with permission [47]. Copyright 2018, Springer Nature. 
ortho and ortho' phenolic hydroxyl substituent group of the parent FeTPP (Fig. 2a) remarkably speeded up the $\mathrm{CO}_{2} \mathrm{RR}$, achieving a CO Faradaic efficiency above $90 \%$ in a mixed DMF-water solvent. In a recent study, carbon electrodes covered with perfluorinated cobalt phthalocyanine (CoFPc) exhibit much higher $\mathrm{CO}_{2} \mathrm{RR}$ performance than the parent $\mathrm{CoPc}$ with a maximum CO Faradaic efficiency of $93 \%$ as shown in Fig. 4a and $4 \mathrm{~b}$ [41]. The Co(II)/Co(I) redox wave and spectroelectrochemical signal of metal-to-ligand transfer confirmed the formation of active Co(I)Pc species. They propose that the electron-deprived CoFPc promotes the desorption of associated $\mathrm{CO}$ and facilitates the active $\mathrm{Co}(\mathrm{I})$ regeneration, thus CoFPc is more selective and active than CoPc. Similarly, Wang et al. [42] immobilized CoPc onto carbon nanotubes and found that the introduction of electron-withdrawing cyano groups to the CoPc further improved the $\mathrm{CO}_{2} \mathrm{RR}$ activity with much higher current density and CO Faradaic efficiency exceeding 95\% (Fig. 4c and 4d).

Most macrocyclic complexes suffer from low conductivity and poor solubility in water, thus anchoring them onto electrode surface or solid supports (usually carbon materials) makes them possible to act as efficient heterogeneous catalysts towards $\mathrm{CO}_{2} \mathrm{RR}$ in aqueous electrolytes. Non-covalent adsorption, covalently bonding and polymerization are common protocols that are used to construct hybrid catalysts [25]. Unequivocally, a proper grafting method should take a suitable support material for better electron transfer and avoid blocking catalytic sites or impeding conductivity. In a comparative study, cobalt meso-tetraphenylporphyrin (CoTPP) alone shows a poor
$\mathrm{CO}_{2} \mathrm{RR}$ performance as a homogeneous catalyst; however, a facile immobilization of CoTPP onto carbon nanotubes remarkably facilitates the $\mathrm{CO}_{2} \mathrm{RR}$, resulting in a substantial enhancement with much improved CO Faradaic efficiency (>90\%) and lower overpotential in aqueous medium [48]. Recently, Li et al. [43] employed an organic-inorganic hybridization strategy to construct cobalt polyphthalocyanine (CoPPc)-sheathed carbon nanotubes (CoPPc/CNT) for highly efficient $\mathrm{CO}_{2} \mathrm{RR}$ (Fig. 5a). The thin conformal polymer coating layer achieved by in-situ polymerization of CoPc molecules helps suppress the aggregation of organic molecules and promote the exposure of more Co-N sites, and thus contributes to an excellent performance with a high CO Faradic efficiency of $\sim 90 \%$, considerable turnover frequency (TOF) of $4900 \mathrm{~h}^{-1}$ at $\eta=0.5 \mathrm{~V}$, and stability of $>24 \mathrm{~h}$, much superior to CoPc and CoPPc alone (Fig. $5 \mathrm{~b}$ and 5c).

\section{Metal organic frameworks (MOFs)}

As mentioned above, polymerization of molecular catalysts on support materials is a wise way to improve the density of active sites $[43,49]$. However, it is not an optimal way for full accessibility of active sites due to the stacking of densely packed structure. Metal-organic frameworks (MOFs) as a class of coordination polymers with open frameworks, consist of metal ions that are linked together by organic ligands [50]. With the large availability of different metal centers, multiple organic ligands and various building blocks, the structure and functionality of MOFs can be tailored to a large extent for tar-
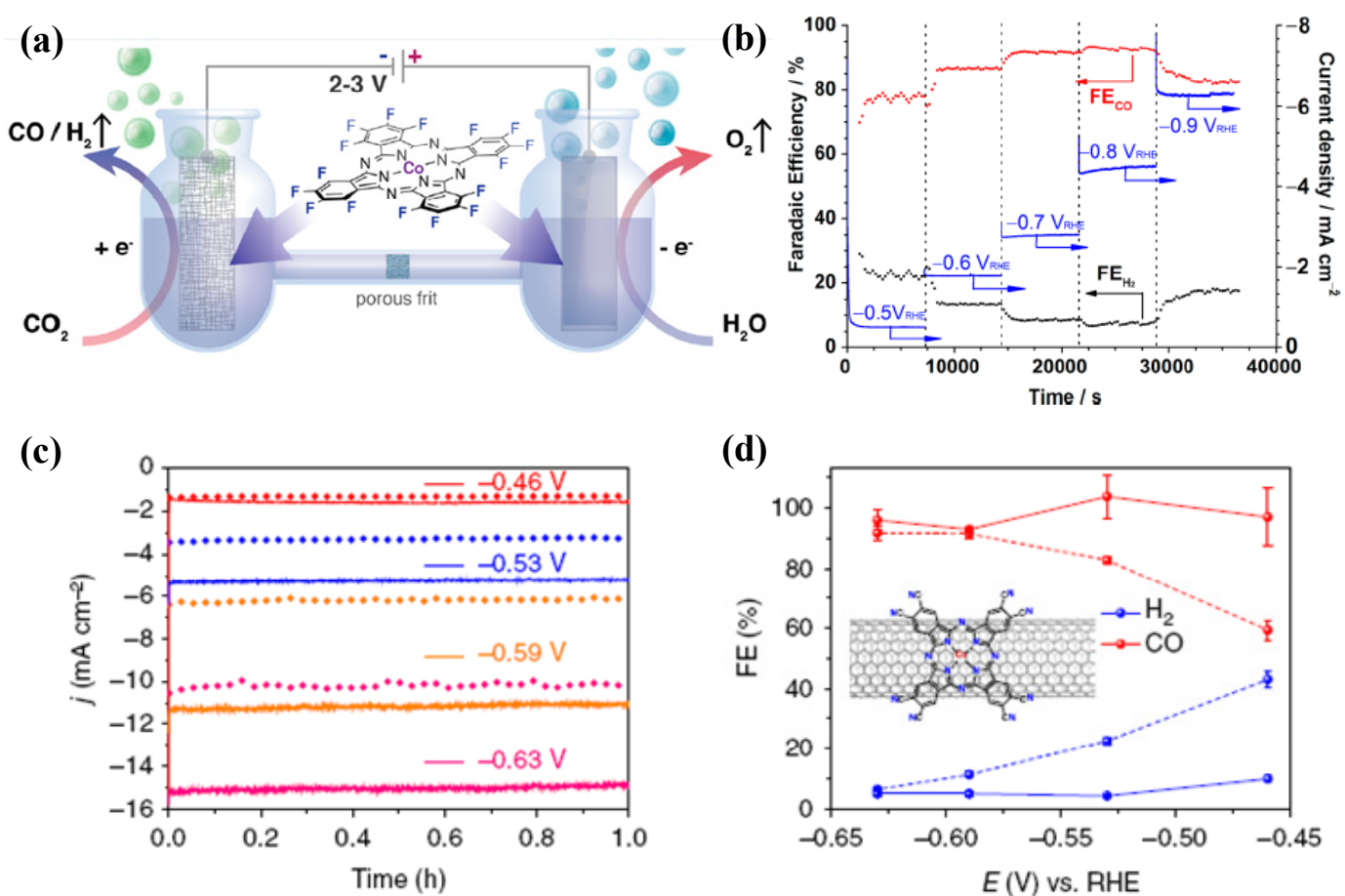

Fig. 4. (a) Schematic illustration for $\mathrm{CO}_{2} \mathrm{RR}$ and (b) CO Faradaic efficiency and current density for controlled-potential electrolysis in 0.5 mol $\mathrm{L}^{-1} \mathrm{Na}-$ $\mathrm{HCO}_{3}$ over CoFPc. Reproduced with permission [41]. Copyright 2016, American Chemical Society. (c) Comparison of chronoamperograms and (d) potential-dependent Faradaic efficiencies between CoPc-CN/CNT (solid line) and CoPc/CNT (dotted line). Reproduced with permission [42]. Copyright 2017, Springer Nature. 
(a)
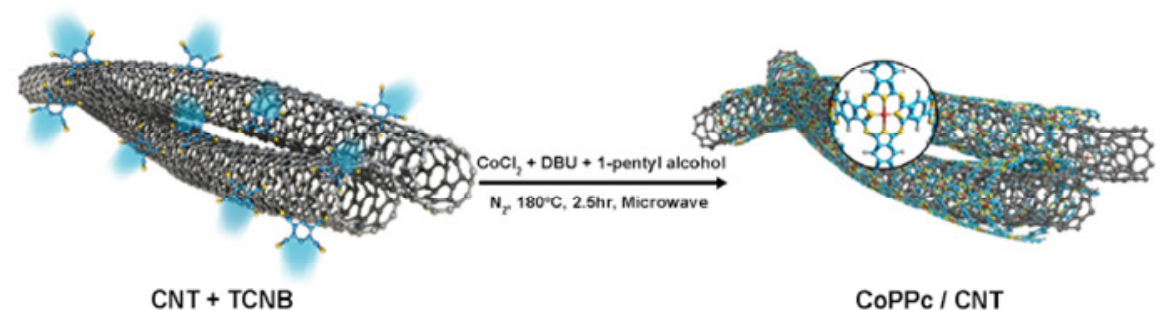

CoPPc / CNT

(b)

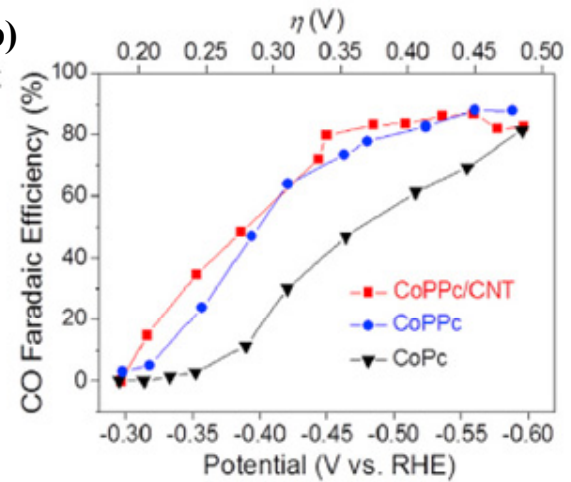

(c)

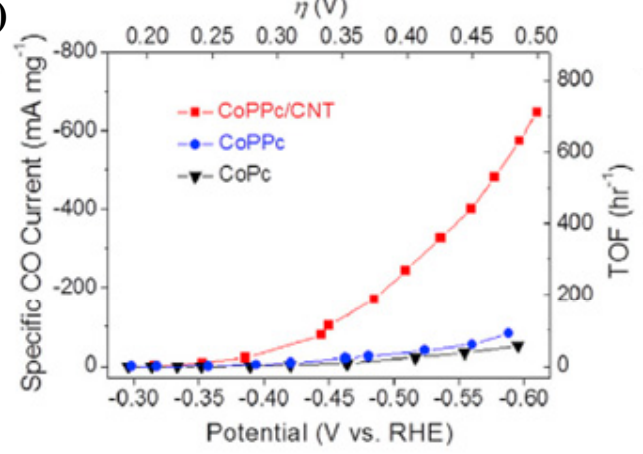

Fig. 5. (a) Illustrated diagrams for the preparation of CoPPc/CNT; (b) CO Faradic efficiency and (c) specific CO current and corresponding TOF values for CoPPc/CNT, CoPPc, and CoPc. Reproduced with permission [43]. Copyright 2017, Elsevier.

geted reaction [50,51]. In addition, such ordered porous structures not only promote the exposure of active sites but also facilitate mass transfer during the catalytic reaction, making MOFs ideal materials for catalysis [52,53].

Recently, following the urgent demand for efficient $\mathrm{CO}_{2}$ conversion process and renewed interest in $\mathrm{CO}_{2} \mathrm{RR}$, MOFs containing $\mathrm{Cu}, \mathrm{Fe}, \mathrm{Co}, \mathrm{Re}$ and $\mathrm{Zn}$, etc., have been investigated as efficient catalysts for $\mathrm{CO}_{2} \mathrm{RR}$ (Fig. 6) [54-59]. Similar to the case in $\mathrm{M}-\mathrm{N}_{x}$-containing macrocyclic complexes, MOFs suffering from low conductivity are always anchored to conductive sur- (a)

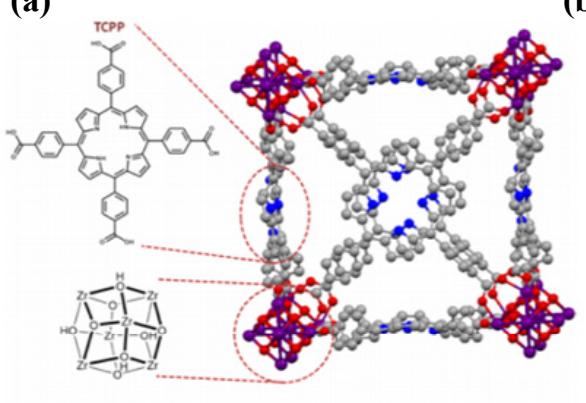

(c)

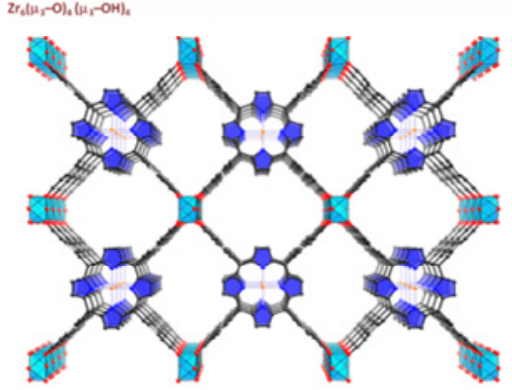

(b)

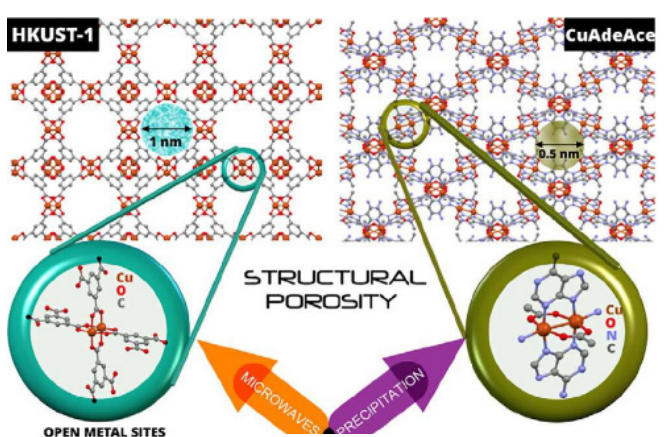

(d)

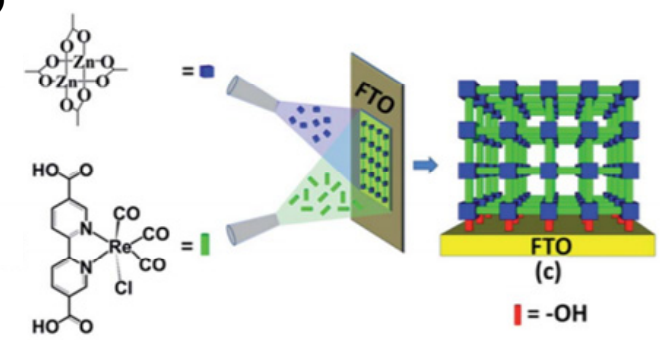

Fig. 6. Typical examples of MOFs studied as efficient catalysts towards $\mathrm{CO}_{2} \mathrm{RR}$. (a) Incorporating Fe porphyrin into MOF- 525 for efficient $\mathrm{CO}_{2} \mathrm{RR}$, the crystal structure including the chemical structure of the TCPP linker and the $\mathrm{Zr}_{6}$-based node were shown here. Reproduced with permission [54]. Copyright 2015, American Chemical Society. (b) Illustrated scheme for the structure of the selected Cu-based metal-organic porous materials for $\mathrm{CO}_{2} \mathrm{RR}$ measurements. Reproduced with permission [55]. Copyright 2017, Wiley-VCH. (c) Building blocks for the $\mathrm{Al}_{2}(\mathrm{OH})_{2} \mathrm{TCPP}-\mathrm{Co}$ assembled thin-film 3D MOF for electrocatalytic reduction of $\mathrm{CO}_{2}$ (Co, orange; $\mathrm{O}$, red; C, black; N, blue; Al, light-blue; pyrrole ring, blue). Reproduced with permission [56]. Copyright 2015, American Chemical Society. (d) Highly oriented Re-based MOF thin film deposited on conductive FT0 electrode for the selective $\mathrm{CO}_{2}$ electroreduction to CO. Reproduced with permission [57]. Copyright 2016, the Royal Society of Chemistry. 
faces or mixed with conductive carbon materials in $\mathrm{CO}_{2} \mathrm{RR}$ $[54,56,59]$. Besides, modification or replacement of linked ligands with better electron/proton transfer ones also significantly help improve the charge/electron transfer capability [60-62]. Yamada et al. [63] first reported a Cu-containing MOF dropped on carbon paper for $\mathrm{CO}_{2} \mathrm{RR}$ in 2012. A copper rubeanate (CR-MOF) was chosen owing to its excellent electronic and proton conductivity arising from the coalescent of a proton with the nitrogen atom and accompanying of electron transfer from $\mathrm{Cu}(\mathrm{II})$ ions. $\mathrm{CO}_{2} \mathrm{RR}$ measurements were conducted in aqueous electrolyte and the results showed that the CR-MOF electrode endowed much lower overpotential, namely $0.2 \mathrm{~V}$ less than that of a $\mathrm{Cu}$ metal electrode, and $\mathrm{HCOOH}$ was the primary product with a Faradaic efficiency of 30\%. Later work from Kulandainathan et al. [64] manifested that $\mathrm{Cu}_{3}(\mathrm{BTC})_{2}$ thin film deposited on glassy carbon (GC) electrode reduced $\mathrm{CO}_{2}$ to oxalate with a Faradaic efficiency of $51 \%$ in $\mathrm{CO}_{2}$-saturated $\mathrm{N}, \mathrm{N}$-dimethylformamide containing tetrabutylammonium tetrafluoroborate. They proposed that $\mathrm{Cu}(\mathrm{I})$ formed at $-0.62 \mathrm{~V}$ vs. $\mathrm{Ag} / \mathrm{Ag}^{+}$in the $\mathrm{CO}_{2}$-saturated DMF solution catalyzed the reduction and the adsorbed $\mathrm{CO}_{2}$ gas inside the pores facilitated the $\mathrm{CO}_{2} \mathrm{RR}$.

Yaghi et al. [65] first tried to incorporate $\mathrm{CO}_{2} \mathrm{RR}$-efficient Co porphyrin building units into covalent organic frameworks (COFs, a subgroup of MOFs with better conductivity due to conjugated double bonds) by organic ligands through imine bonds (Fig. 7a and 7b). They reported that COF-366-Co synthe- sized by the connection of 5,10,15,20-tetrakis(4-aminophenyl) porphinato cobalt [Co(TAP)] with 1,4-benzenedicarboxaldehyde (BDA) displayed a high CO Faradaic efficiency (90\%) when deposited on conductive carbon fabric for $\mathrm{CO}_{2} \mathrm{RR}$ measurements. In addition, modifications through modular protocols by appropriate combinations of building units further promote the reaction activity. When biphenyl 4,4'-dicarboxaldehyde (BPDA) with longer chain was used as the strut substituting for BDA, lattice expanding results in a larger pore radius and allows for a higher $\mathrm{CO}_{2}$ adsorption capacity and increased accessibility of the active sites. Copper porphyrin, which is catalytically inactive for $\mathrm{CO}_{2} \mathrm{RR}$, was used to dilute cobalt porphyrin active sites and further improve the turnover frequency of active Co sites. Consequently, COF-367-Co (1\%) with only 1\% Co in all metal sites exhibited an initial TOF EA of $9400 \mathrm{~h}^{-1}$, equivalent to a 26-fold higher than the activity of the parent $\mathrm{Co}$ (TAP). In another work, the same group took $\mathrm{Al}_{2}(\mathrm{OH})_{2} \mathrm{TCPP}-\mathrm{Co} \quad\left(\mathrm{TCPP}-\mathrm{H}_{2}=\right.$ $4,4^{\prime}, 4^{\prime \prime}, 4^{\prime \prime \prime}$-(porphyrin-5,10,15,20-tetrayl)tetrabenzoate) as the linker units and assembled them into a porous thin film MOF directly grown on a conductive substrate through atomic layer deposition (ALD) technique (Fig. 7c-e) [56]. The thickness of the MOF film was optimized by precise regulation of ALD cycles and such catalytic system displayed a CO Faradaic efficiency exceeding $76 \%$ and remained stable over 7 h. Operando spectroelectrochemical measurements showed that the majority of Co(II) catalytic centers in the MOF were electro-reduced to

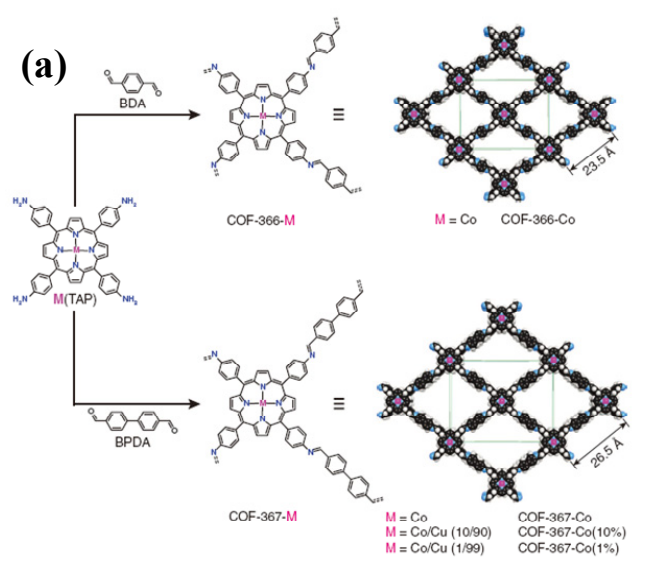

(c)

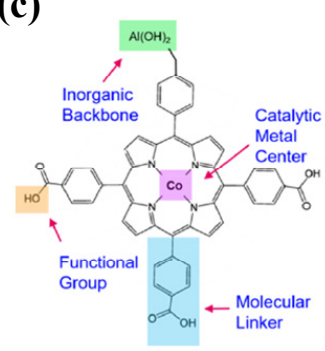

(d)

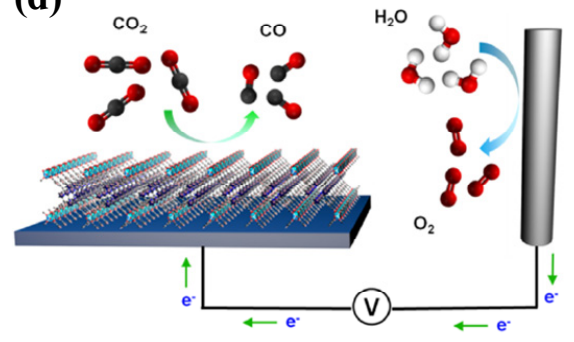

(b)

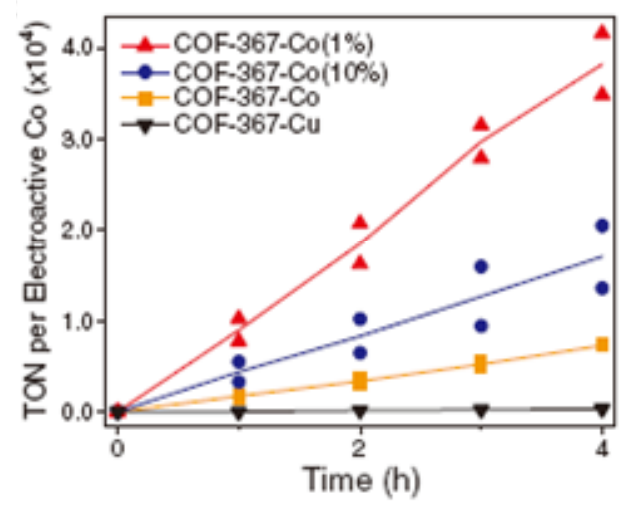

(e)

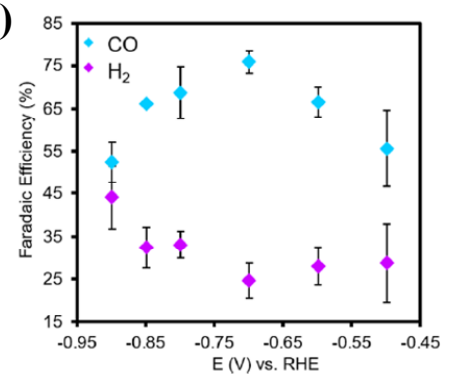

Fig. 7. (a) Design and synthesis of metal porphyrin-derived 2D COF; (b) TON numbers with respect to the amount of cobalt porphyrin for CO production at -0.67 V (vs. RHE) over COF-367-Co (1\%), COF-367-Co, COF-367-Co, or COF-367-Cu. Reproduced with permission [65]. Copyright 2015, The American Association for the Advancement of Science. (c) The tailorable molecular structure of $\mathrm{Al}_{2}(\mathrm{OH})_{2} \mathrm{TCPP}-\mathrm{Co}$; (d) Each carboxylate from $\mathrm{Al}_{2}(\mathrm{OH})_{2}$ TCPP-Co is combined with the aluminum inorganic backbone to assemble into a 3D MOF on a conductive substrate for a feasible CO ${ }_{2} \mathrm{RR}$ system; (e) Product selectivity during $\mathrm{CO}_{2}$ electrolysis in a potential range of -0.5 to -0.9 vs. RHE. Reproduced with permission [56]. Copyright 2015, American Chemical Society. 
$\mathrm{Co}(\mathrm{I})$ and subsequently catalyzed the $\mathrm{CO}_{2} \mathrm{RR}$. The direct growth of the MOF onto the conductive surface is indeed an effective way for increasing the portion of electroactive sites and enhancing the charge-transport properties for MOFs materials, thus leading to a higher $\mathrm{CO}_{2} \mathrm{RR}$ performance.

MOFs composed of metal nodes and organic linkers potentially combine the advantages of both molecular and heterogeneous catalysts. A precise manipulation of its building units allows for changes on both spatial arrangement (i.e., porous structure, topology of the structure) and electronic environment, offering a great possibility for efficient $\mathrm{CO}_{2} \mathrm{RR}$. Yet, the low conductivity of MOFs still restricted the exposure of electro-active sites, leading to a limited current density.

\section{Carbon-based metal-nitrogen materials}

Pyrolyzed metal-nitrogen-carbon materials have been widely used as promising candidates for the oxygen reduction reaction (ORR) owing to their low cost and earth-abundant components. Progress in the synthesis, characterization, ORR performance and reaction mechanisms is well summarized in related review papers [66-68]. Strasser et al. [11] firstly tried to use porous carbon materials doped with $\mathrm{M}-\mathrm{N}_{X}$ sites, derived from the pyrolysis of nitrogen and $\mathrm{Fe}-$ and/or Mn-functionalized commercial carbon for $\mathrm{CO}_{2} \mathrm{RR}$, with $\mathrm{CO}$ as the major product and a trace amount of $\mathrm{CH}_{4}$ was detect on Fe-containing catalysts (Fig. 8). Their results confirm that metal-nitrogen-carbon (M-N-C) materials are efficient in $\mathrm{CO}_{2} \mathrm{RR}$ and have stimulated an academic research boom on carbon-based metal-nitrogen materials towards $\mathrm{CO}_{2} \mathrm{RR}$. In analogy to the 4-electron ORR, electroreduction of $\mathrm{CO}_{2}$ to $\mathrm{CO}$ or hydrocarbons involves multiple coupled protonation/reduction steps and thereby there are some common strategies for constructing highly effective $\mathrm{M}-\mathrm{N}_{X}$-containing carbon materials towards $\mathrm{CO}_{2} \mathrm{RR}$.

Carbon-based $\mathrm{M}-\mathrm{N}_{x}$-doped materials are always prepared by a facile pyrolysis of mixtures composed of metal-, nitrogenand carbon-containing precursors. During the pyrolysis, N- and C-containing precursors decomposed and transformed into $\mathrm{N}$-doped carbon, while metal sites coordinated to $\mathrm{N}$ atoms were simultaneously embedded into the skeleton. Thus the mixed precursors and appropriate pyrolysis parameters concerning carbonization temperature and duration time are of vital importance for constructing atomically dispersed $\mathrm{M}-\mathrm{N}_{X}$-containing materials $[30,69,70]$. Notably, to avoid the formation of metal nanoparticles which mainly promote the competitive HER, precursors with well-dispersed M- $\mathrm{N}_{x}$ structures or spatial confining metal sites are preferred and acid-leaching process is available for removing these undesirable nanoparticles. Recently, Jiang et al. [71] developed a multistep pyrolysis process to synthesize a class of single-atom catalysts on nitrogen-doped carbon nanotubes (MSA-N-CNTs) with an extraordinary high metal loading. The reconnaissance study revealed that Ni-g- $\mathrm{C}_{3} \mathrm{~N}_{4}$ with $\mathrm{Ni}$ single atoms located in the cavity of g- $\mathrm{C}_{3} \mathrm{~N}_{4}$ formed when the mixture was further pyrolyzed at $650{ }^{\circ} \mathrm{C}$ followed by the first heat treatment at $350{ }^{\circ} \mathrm{C}$. Thanks to the strong covalent bonding between $\mathrm{g}-\mathrm{C}_{3} \mathrm{~N}_{4}$ and $\mathrm{Ni}$ atoms, aggregation of $\mathrm{Ni}$ atoms was inhibited at higher temperature (700-900 ${ }^{\circ} \mathrm{C}$ ), giving rise to the atomically dispersed NiSA-N-CNTs. MOFs or ZIFs (zeolitic imidazolate frameworks), in which metal nodes are separated by organic linkers (especially $\mathrm{N}$-containing ligands), have been used as ideal precursors to help increase the loading of atomically dispersed metal sites within the final porous carbon materials. In particular, metal residing in MOF/ZIF can be partly exchanged with other metals, thus allowing further increasing of the spatial distance of metal sites. For example, the $\mathrm{Zn}^{2+}$ sites in ZIF-8/ZIF-7 are replaceable with $\mathrm{Co}^{2+}, \mathrm{Ni}^{2+}$ and $\mathrm{Fe}^{3+} / \mathrm{Fe}^{2+}$ ions, and subsequently serve as perfect spacer for adjacent $\mathrm{Co} / \mathrm{Ni} / \mathrm{Fe}$ atoms to avoid the agglomeration of metal atoms during the pyrolysis. Typical work on mixed metal ZIF precursors is shown in Fig. 9 $[31,70,72]$. Namely, $\mathrm{Zn}$ atoms with low boiling point evaporated away at temperatures over $800{ }^{\circ} \mathrm{C}$, while $\mathrm{Co} / \mathrm{Ni} / \mathrm{Fe}$ nodes are reduced in situ and anchored in the carbon skeleton with $\mathrm{N}$-coordination. Li's group [70,73] has done intense work on the synthesis of single-atom catalysts by pyrolyzing ZIF-related materials, and they also found that coordination number could be regulated by pyrolyzing temperature because $\mathrm{M}-\mathrm{N}$ coordination bonds were vulnerable at higher temperature. Our work on ZIF-derived M-N-C catalysts further highlights the vital role (a)

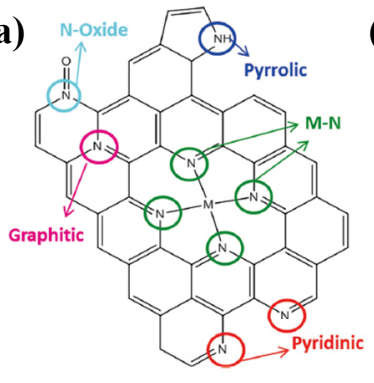

(b)

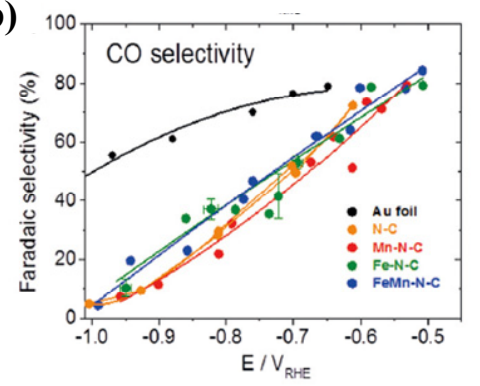

(c)

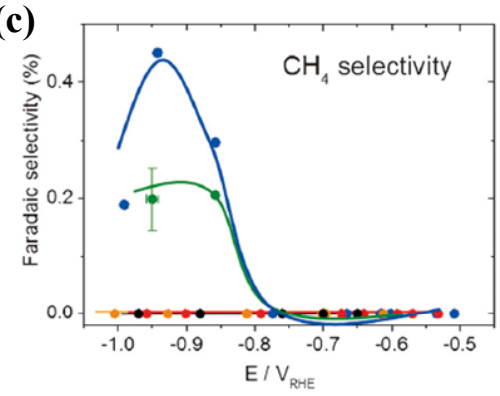

Fig. 8. (a) Schematic structure of nitrogen atoms in different coordinated configurations in the synthesized N-C materials; (b) $\mathrm{CO}$ and (c) $\mathrm{CH}_{4}$ Faradaic efficiencies on gold (black), N-C (orange), Mn-N-C (red), Fe-N-C (green) and FeMn-N-C (blue). Reproduced with permission [11]. Copyright 2015, Wiley-VCH. 

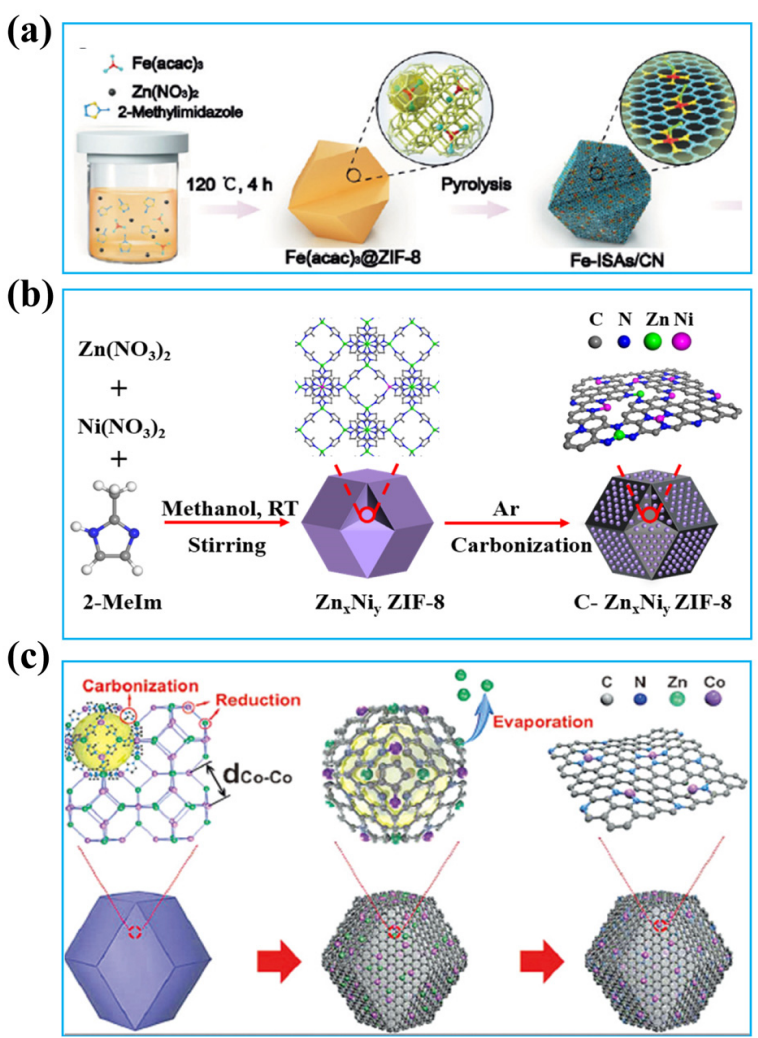

Fig. 9. Schematic illustration of the synthesis of (a) F-N-C. Reproduced with permission [72]. Copyright 2017, Wiley-VCH. (b) Ni-N-C. Reproduced with permission [31]. Copyright 2018, the Royal Society of Chemistry. Copyright 2017, Wiley-VCH. (c) Co-N-C materials using $\mathrm{Fe} / \mathrm{Ni} / \mathrm{CoZn}$ bimetallic ZIF as precursors. Reproduced with permission [70]. Copyright 2016, Wiley-VCH.

of doping methods. We disclosed that introducing a second transition metal ion $\left(\mathrm{Ni}^{2+}\right.$ or $\left.\mathrm{Fe}^{3+}\right)$ during the crystallization of ZIF-8 could maximize the doping concentration of atomically dispersed metal sites compared with the post-synthetic ion exchange method, while post impregnation with specific metal salts (ammonium ferric citrate) helped to confine the $\mathrm{Fe}^{3+}$ on the surface of ZIF-8, leading to a high exposure of iron-nitrogen sites [31,32].

Similar to the rules explored in $\mathrm{M}-\mathrm{N}_{X^{-}}$-containing macrocyclic complexes, metal centers and their coordination state play an important role in product selectivity. Recent work on $\mathrm{M}-\mathrm{N}_{x}$ active sites for $\mathrm{CO}_{2} \mathrm{RR}$ revealed that $\mathrm{Fe}-\mathrm{N}, \mathrm{Co}-\mathrm{N}, \mathrm{Ni}-\mathrm{N}, \mathrm{Mn}-\mathrm{N}$, $\mathrm{Zn}-\mathrm{N}$ and $\mathrm{Sn}-\mathrm{N}$ sites are effective towards $\mathrm{CO}_{2} \mathrm{RR}$ [31,32,73-82]. Fontecave et al. [74] examined a series of iron-based catalysts containing $\mathrm{Fe}-\mathrm{N}$ sites for $\mathrm{CO}_{2} \mathrm{RR}$ and unveiled that $\mathrm{FeN}_{4}$ sites facilitated $\mathrm{CO}_{2} \mathrm{RR}$ to $\mathrm{CO}$ and Fe-based nanoparticles favored the production of undesirable $\mathrm{H}_{2}$ (Fig. 10a). Thus by synthetically regulating the ratio of $\mathrm{Fe}$-based nanoparticles to isolated $\mathrm{FeN}_{4}$ sites, products with controlled $\mathrm{CO} / \mathrm{H}_{2}$ ratios can be obtained. In addition to the intrinsic nature of active sites, the mass transfer ability and high exposure of active sites are also crucial for the catalytic performance [83-85]. Recently, our group [32] took a post-synthetic modification strategy to prepare highly exposed Fe-N active sites through surface functionalization of ZIF-8 with ammonium ferric citrate (AFC). The C-AFC@ZIF-8 with highly exposed Fe- $\mathrm{N}$ sites exhibited superior selectivity and mass activity towards $\mathrm{CO}_{2} \mathrm{RR}$ than its counterpart derived from bulk functionalization of ZIF-8 with similar Fe loading, reaching a maximum $\mathrm{FE}_{\mathrm{co}}$ of $93.0 \%$ at $-0.43 \mathrm{~V}$ (Fig. 10b). We also employed a post-synthetic strategy by a second pyrolysis in ammonia to further improve the performance of Fe-N sites [75]. With aid of the etching effect of ammonium at high temperature, the removal of residual $\mathrm{Zn}$ species and vulnerable carbon moieties further maximized the exposure of Fe- $\mathrm{N}$ active sites and facilitated mass transfer during the $\mathrm{CO}_{2} \mathrm{RR}$. Therefore, the optimal catalyst after an additional pyrolysis in ammonium showed a remarkable increase in both FEco and current density, exceeding other efficient Fe-N-C catalysts (Fig. 10c). Lin et al. [86] developed a composite material composed of pyrolyzed ZIFs and carbon nanotubes for $\mathrm{CO}_{2} \mathrm{RR}$, which manifests nearly $100 \%$ CO Faradaic efficiency at an overpotential of $740 \mathrm{mV}$. Moreover, when little amount of Fe was doped into the catalyst, the overpotential was further decreased to $440 \mathrm{mV}$. They ascribed such superior activity to the enhanced electron transport and expedited $\mathrm{CO}_{2}$ transport resulted from the MWCNT support. Chen et al. [76] found that the CO Faradaic efficiency drops with decreasing $\mathrm{Co}-\mathrm{N}_{x}$ coordination number. CoPc was loaded onto hollow N-doped porous carbon spheres (HNPCSs) starting from polymer precursors by efficient coordination with abundant $\mathrm{N}$ sites in HNPCSs support. EXAFS fitting results revealed that the $\mathrm{Co}-\mathrm{N}$ coordination number is 5 . Co-N $\mathrm{N}_{4} / \mathrm{HNPCSs}$ and Co-N 3 /HNPCSs catalysts were obtained by pyrolyzing Co- $\mathrm{N}_{5} / \mathrm{HNPCSs}$ at 400 and $600{ }^{\circ} \mathrm{C}$, whereas higher temperatures $\left(800\right.$ and $\left.1000{ }^{\circ} \mathrm{C}\right)$ result in the formation of NPs. Electrocatalytic results display that CO Faradaic efficiency remains stable at about $90 \%$ from $-0.57 \mathrm{~V}$ to $-0.88 \mathrm{~V}$ vs. RHE on Co- $\mathrm{N}_{5} / \mathrm{HNPCSs}$, superior to other counterparts.

As presented above, Fe-N-C/Co-N-C catalysts demonstrated impressive $\mathrm{CO}$ Faradaic efficiency at relatively low overpotentials; however, a drawback for future application is that the Faradaic efficiency drops rapidly accompanying an increase in the overpotential for much higher current density [11,32,73-75]. Ni-N-C materials were also examined for $\mathrm{CO}_{2} \mathrm{RR}$ and the results showed that $\mathrm{Ni}-\mathrm{N}-\mathrm{C}$ catalysts outperformed $\mathrm{Fe}-\mathrm{N}-\mathrm{C} / \mathrm{Co}-\mathrm{N}-\mathrm{C}$ counterparts at slightly larger overpotentials [77-80].

Coordinatively unsaturated $\mathrm{Ni}-\mathrm{N}_{x}$ active sites embedded in porous carbon were synthesized by facile heat treatment of $\mathrm{Zn} / \mathrm{Ni}$ bimetallic ZIF-8 at 900 and $1000{ }^{\circ} \mathrm{C}$. Nickel was doped during the crystallization process and the maximum loading of atomically dispersed $\mathrm{Ni}$ reached $5.44 \mathrm{wt} \% . \mathrm{CO}_{2} \mathrm{RR}$ measurements in $1 \mathrm{~mol} \mathrm{~L}^{-1} \mathrm{KHCO}_{3}$ electrolyte showed that $\mathrm{FE}_{\mathrm{co}}$ was kept between $92.0 \%$ and $98.0 \%$ in a higher overpotential window ranging from $-0.53 \mathrm{~V}$ to $-1.03 \mathrm{~V}$ (vs. RHE), and thereby CO current density increases with the applied potential and reaches $71.5 \pm 2.9 \mathrm{~mA} \mathrm{~cm}^{-2}$ at $-1.03 \mathrm{~V}$ (vs. RHE) (Fig. 11a and 11b), breaking the limit in Fe-N-C/Co-N-C materials [31]. Based on the unsaturated coordination structure of $\mathrm{Ni}-\mathrm{N}_{X}$ sites obtained from XAS analysis, density functional theory calculations stimulated three $\mathrm{Ni}-\mathrm{N}$ active sites $\left(\mathrm{NiN}_{3}, \mathrm{NiN}_{3} \mathrm{~V}\right.$ and $\left.\mathrm{NiN}_{2} \mathrm{~V}_{2}\right)$ and free energies of major intermediates were employed to unveil the activity trend. Specifically, theoretical results revealed that the 
(a)

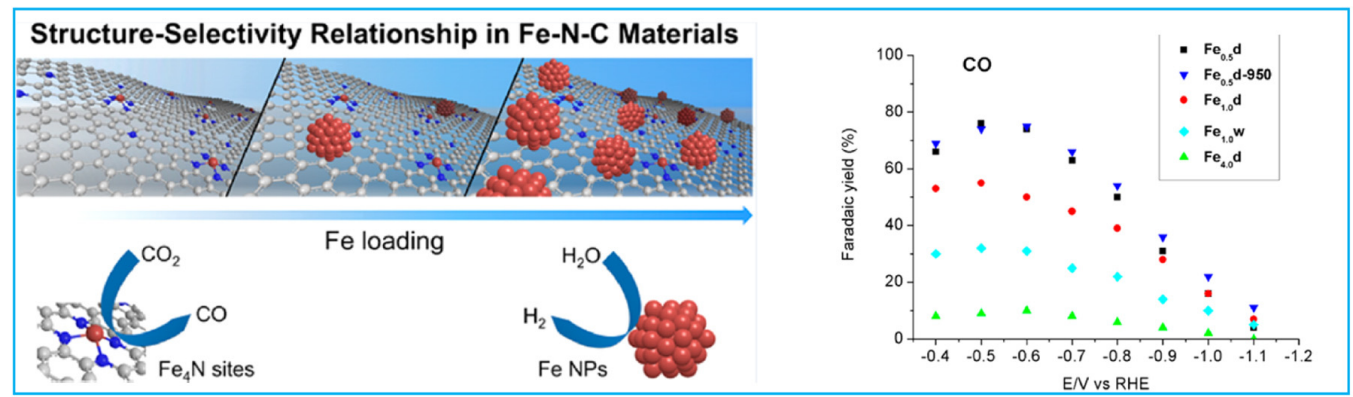

(b)

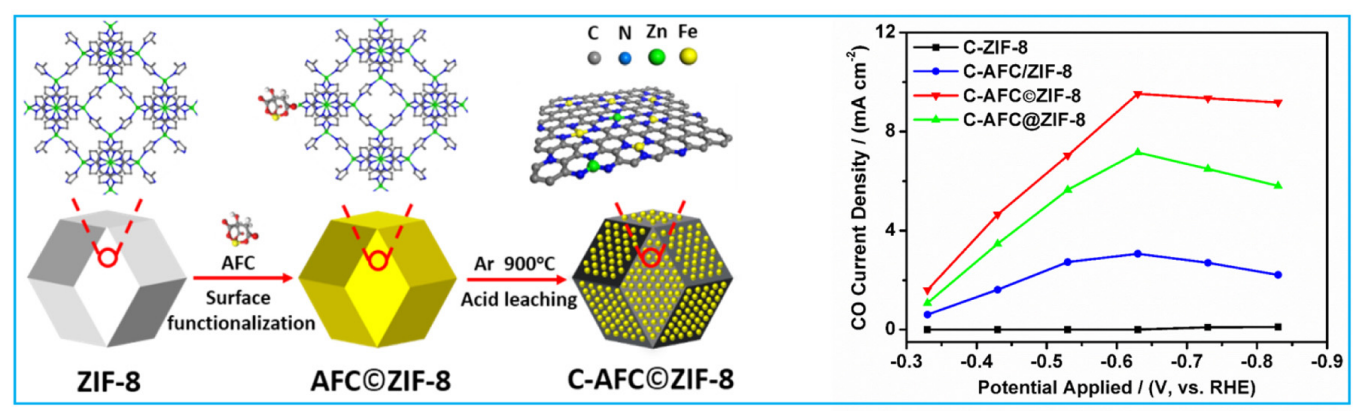

(c)

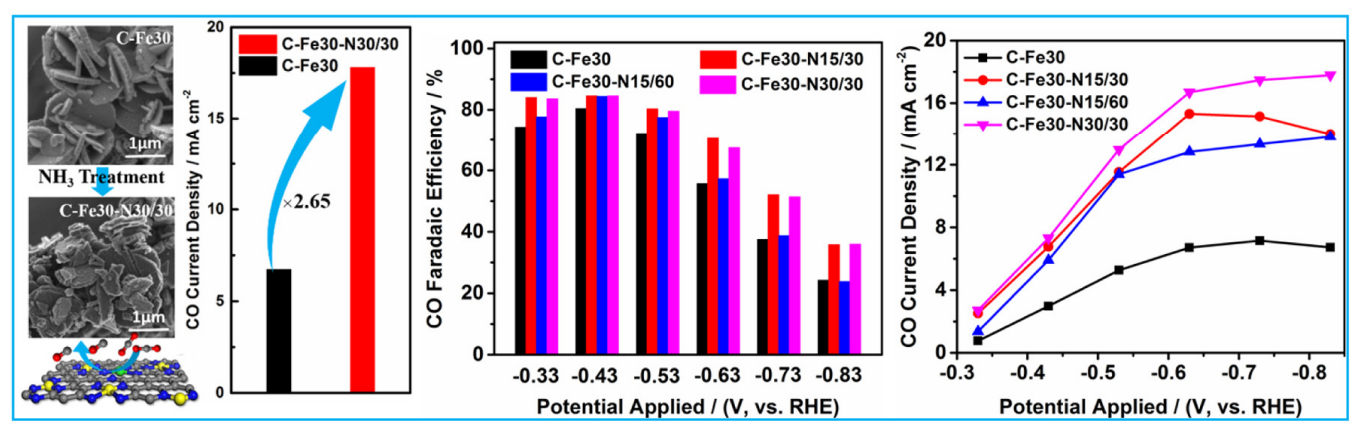

Fig. 10. Reported Fe-N-C catalysts for $\mathrm{CO}_{2}$ RR. (a) Structure-selectivity relationships in Fe-N-C materials. Reproduced with permission [74]. Copyright 2017, American Chemical Society. (b) Enhanced exposure of Fe-N active sites through confining AFC molecule on the surface of ZIF-8, where C-AFC/ZIF-8 stands for the sample derived from pyrolysis of mechanically blended ZIF-8 and AFC mixture, while C-AFC@ZIF-8 refers to the sample synthesized though a bulk functionalization method. Reproduced with permission [32]. Copyright 2017, Elsevier. (c) Improving $\mathrm{CO}_{2} \mathrm{RR}$ performance over the ZIF-derived Fe-N material by a second pyrolysis in ammonia. Reproduced with permission [75]. Copyright 2018, Elsevier.

free energies of ${ }^{*} \mathrm{COOH}\left(G^{*} \mathrm{COOH}\right)$ on coordinatively unsaturated $\mathrm{NiN}_{3}, \mathrm{NiN}_{3} \mathrm{~V}$ and $\mathrm{NiN}_{2} \mathrm{~V}_{2}$ were significantly lower than those on $\mathrm{NiN}_{4}$, and the ${ }^{*} \mathrm{H}$ blockage was relatively weak on $\mathrm{NiN}_{3} \mathrm{~V}$ and $\mathrm{NiN}_{2} \mathrm{~V}_{2}$ structures, confirming that the high $\mathrm{CO}_{2} \mathrm{RR}$ performance resulted from those coordinatively unsaturated Ni-N sites (Fig. $11 \mathrm{c}$ and $11 \mathrm{~d}$ ).

As mentioned above, various transition metal-functionalized carbon/nitrogen precursors and different approaches were employed to construct carbon-based metal-nitrogen materials, leading to discrepancies in carbon architectures (porosity, composition and structure), M-N coordination structure and nitrogen doping state (contents and configurations). In order to understand the role of metal centers and identify a champion metal for the construction of optimal $\mathrm{M}-\mathrm{N}_{x}$-containing carbon materials towards $\mathrm{CO}_{2} \mathrm{RR}$, atomically dispersed $\mathrm{M}-\mathrm{N}_{x}$ materials with different transition metals should be prepared by the same method, minimizing the effects of carbon and nitrogen variables. Strasser et al. [87] synthesized a family of porous carbon materials doped with active $\mathrm{M}-\mathrm{N}_{x}$ moieties $(\mathrm{M}=\mathrm{Mn}, \mathrm{Fe}$, $\mathrm{Co}, \mathrm{Ni}, \mathrm{Cu}$ ) with transition metal salts and bipyridine-based coordinated polymers as initial precursors for more profound understanding of reactivity trends towards $\mathrm{CO}_{2} \mathrm{RR}$ (Fig. 12a). The $\mathrm{CO}_{2} \mathrm{RR}$ performance greatly depended on the transition metals, both in terms of CO Faradaic efficiency and overpotential, among which Fe-N-C and Ni-N-C outperformed other metal-related porous carbon showing much improved activity while the maximum CO Faradaic efficiency was obtained at a lower overpotential on Fe-N-C $\left(V_{\mathrm{RHE}}=-0.55 \mathrm{~V}, \mathrm{FE}_{\mathrm{CO}}=65 \%\right)$ than on Ni-N-C $\left(V_{\text {RHE }}=-0.78 \mathrm{~V}\right.$, FEco $\left.=85 \%\right)$ (Fig. 12b). DFT simulations of reaction pathways on these catalytically active $\mathrm{M}-\mathrm{N}_{x}$ moieties agreed well with the experimental results (Fig. 12c). Consistent with the experiments, Co- $\mathrm{N}_{x}$ sites holding downhill energetics for hydrogen suffered from severe energetic barriers to $\mathrm{CO}$ production; while larger overpotentials were required for $\mathrm{Ni}-\mathrm{N}_{x}$ sites to start the reaction resulting from the low $\mathrm{H}^{*}$ and $\mathrm{CO}^{*}$ binding energy and at larger overpotentials hydrogen evolution was hindered on $\mathrm{Ni}-\mathrm{N}_{x}$ catalysts with much less energetic barrier for CO production. Reported work from Daasbjerg's and Li's groups $[33,88]$ also confirmed the notable CO Faradaic efficiency of Fe-N-C and Ni-N-C with Ni 

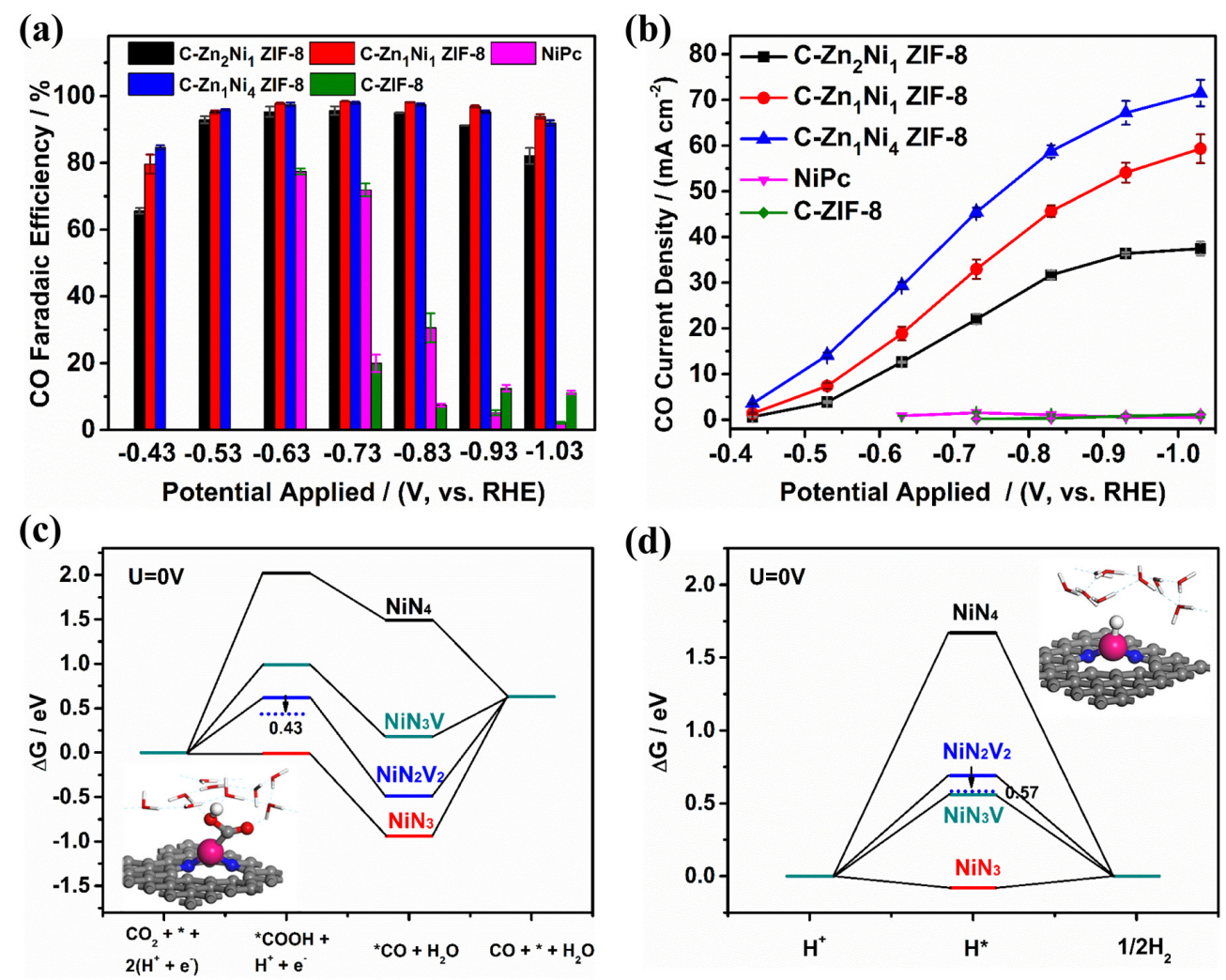

Fig. 11. $\mathrm{CO}_{2} \mathrm{RR}$ performance of Ni-N-C and related contrast catalysts. (a) CO Faradaic efficiency over Ni-N-C samples in a potential range of -0.43 to $-1.03 \mathrm{~V}$ vs. RHE; (b) $\mathrm{CO}$ partial current density measured in $\mathrm{CO}_{2}$-saturated $1 \mathrm{~mol} \mathrm{~L}^{-1} \mathrm{KHCO}_{3}$ solution with a catalyst loading of $2.0 \pm 0.1 \mathrm{mg}$ cm ${ }^{-2}$ for $\mathrm{C}-\mathrm{Zn}_{x} \mathrm{Ni}_{y} \mathrm{ZIF}-8$ and $1.06 \mathrm{mg} \mathrm{cm}^{-2}$ for NiPc; Free energy diagrams with implicit (solid lines) and explicit (dashed lines) solvation effect corrections for (c the $\mathrm{CO}_{2} \mathrm{RR}$ and (d) the HER pathways on $\mathrm{Ni}-\mathrm{N}_{x}$ sites with different proposed $\mathrm{Ni}-\mathrm{N}$ structures at $0 \mathrm{~V}$. Insets: Adsorbed configurations of $* \mathrm{COOH}$ and ${ }^{*} \mathrm{H}$ intermediates on the $\mathrm{NiN}_{2} \mathrm{~V}_{2}$ site, and the $\mathrm{H}, \mathrm{C}, \mathrm{O}, \mathrm{N}$, and $\mathrm{Ni}$ atoms were displayed in white, grey, red, blue, and purple, respectively. Reproduced with permission [31]. Copyright 2018, the Royal Society of Chemistry.

as the champion metal center even at much higher overpotentials.

\section{Reaction parameters and proposed mechanisms}

Despite of the intrinsic activity of the catalysts, reaction parameters such as $\mathrm{pH}$ value of the electrolyte and reactant $\mathrm{CO}_{2}$ pressure also affect the selectivity and activity of $\mathrm{CO}_{2} \mathrm{RR}$. Sonoyama et al. [89] found that metal-meso-tetraphenylporphyrin (MTPP) supported on GDEs exhibited much enhanced activity with less overpotential and higher selectivity at 20 atm compared with at ambient pressure. Higher concentration and faster diffusion rate of $\mathrm{CO}_{2}$ may account for such enhancement. Koper et al. [90] carried out a detailed pH-dependent study for an immobilized cobalt protoporphyrin catalyst, showing that at $\mathrm{pH}=1$ hydrogen evolution reaction dominated and little CO and $\mathrm{CH}_{4}$ formed compared with at $\mathrm{pH}=3$, and further $\mathrm{CO}$ electroreduction to $\mathrm{CH}_{4}$ prefers a more acidic environment (at $\mathrm{pH}=$ 1), as shown in Fig. 13a. The observation that $\mathrm{CO}_{2}$ electroreduction to $\mathrm{CO}$ becomes much more dominate at a high $\mathrm{pH}$, indicating that $\mathrm{CO}_{2}$ activation is not sensitive to the proton concentration, which is obviously different from the competing HER. This result agrees well with the assumption that the formation of a catalyst-bound $\mathrm{CO}_{2}^{--}$radical anion possessing a strong
Brønsted-base character is crucial for initiating $\mathrm{CO}_{2}$ reduction, and therefore the proton donor may be water rather than $\mathrm{H}^{+}$ (Fig. 13b). Analogously, Strasser et al. [91] studied the effect of $\mathrm{pH}$ on the $\mathrm{CO}_{2} \mathrm{RR}$ performance of $\mathrm{Fe}-\mathrm{N}-\mathrm{C}$ catalysts, especially focusing on the selectivity of $\mathrm{H}_{2}, \mathrm{CO}$ and methane to investigate the role of proton concentration on the catalytic reactions. $\mathrm{CO}_{2} \mathrm{RR}$ measurements were performed in $\mathrm{CO}_{2}$-saturated electrolyte at different $\mathrm{pH}$ values between 1 and 7.25. When plotting production rate versus the applied potential (vs. NHE) at different $\mathrm{pH}$ values (Fig. 14a), it was obvious that $\mathrm{H}_{2}$ and $\mathrm{CH}_{4}$ formation depended on the $\mathrm{pH}$, but $\mathrm{CO}$ formation was independent of $\mathrm{pH}$. The $\mathrm{pH}$ dependence observed for $\mathrm{CH}_{4}$ and $\mathrm{H}_{2}$ production was consistent with a rate-determining step involving a coupled-proton-electron transfer. In contrast, the unveiling $\mathrm{pH}$ independence for $\mathrm{CO}$ formation indicated a decoupled electron-proton transfer process (DEPT) in which $\mathrm{CO}_{2}^{--}$anion adduct was a key intermediate (Fig. 14b and 14c) similar with the mechanism proposed by Koper et al. [90,92] in $\mathrm{Co}$ (II)-N-C complexes. Based on the guidance of the above reaction mechanism, important catalyst design rules bearing the DEPT mechanism involve: (i) Reducing the barrier for the formation of the initial catalyst-bound $\mathrm{CO}_{2}^{--}$radical anion by enhancing the interaction between active sites and intermediate is an effective way to decrease the overpotential of $\mathrm{CO}_{2} \mathrm{RR}$; 
(a)

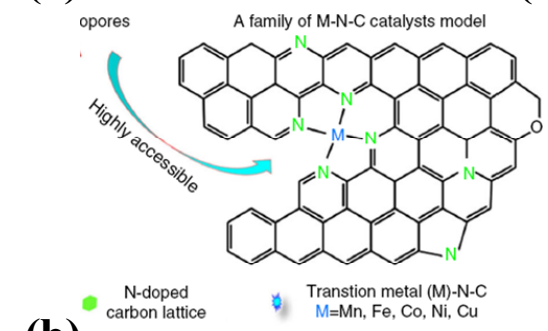

(b)

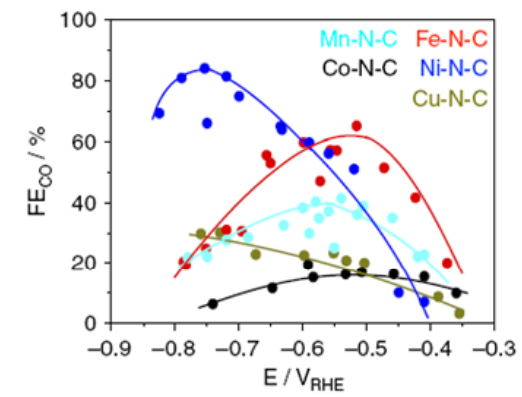

(c)

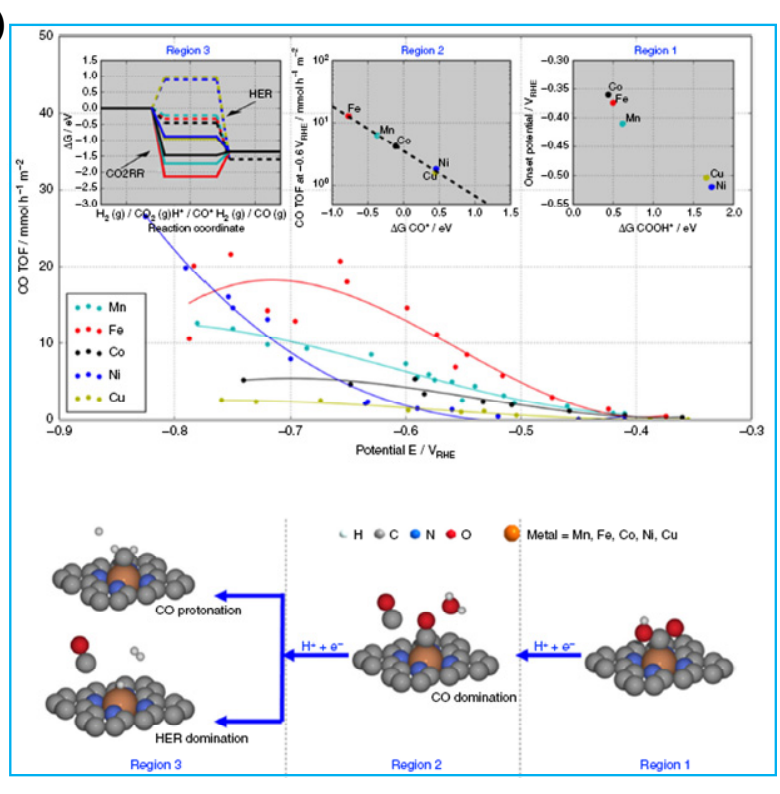

Fig. 12. (a) A schematic local structure of the synthesized $M-\mathrm{N}_{x}$-containing materials; (b) Applied iR-corrected potential dependent CO Faradaic efficiency for the five M-N-C catalysts; (c) Simulation results showing good accordance with experimental measurements. Middle of (c): Applied potential dependent CO production turnover frequency (TOF) over the M-N-C catalysts. Three distinct potential regions for both catalytic performances (upper and reaction pathways (lower) exhibiting different rate-determining mechanistic features. Region 1: Low overpotentials, the onset potentials of CO production correlate with the binding energy of the reaction intermediate $\mathrm{COOH}^{*}$; Region 2: Intermediate overpotentials, the TOF value of CO production at $-0.6 \mathrm{~V}$ vs. RHE correlates with the free energy of adsorbed CO; Region 3: High overpotentials, free energy diagrams for the HER (dashed paths) and $\mathrm{CO}_{2} \mathrm{RR}$ (solid paths) at $-0.8 \mathrm{~V}$ vs. RHE for each $\mathrm{M}-\mathrm{N}-\mathrm{C}$ catalyst showing higher HER barriers for Ni and $\mathrm{Cu}$ with downhill $\mathrm{CO}{ }_{2} \mathrm{RR}$ barrier. Reproduced with permission [87]. Copyright 2017, Springer Nature.
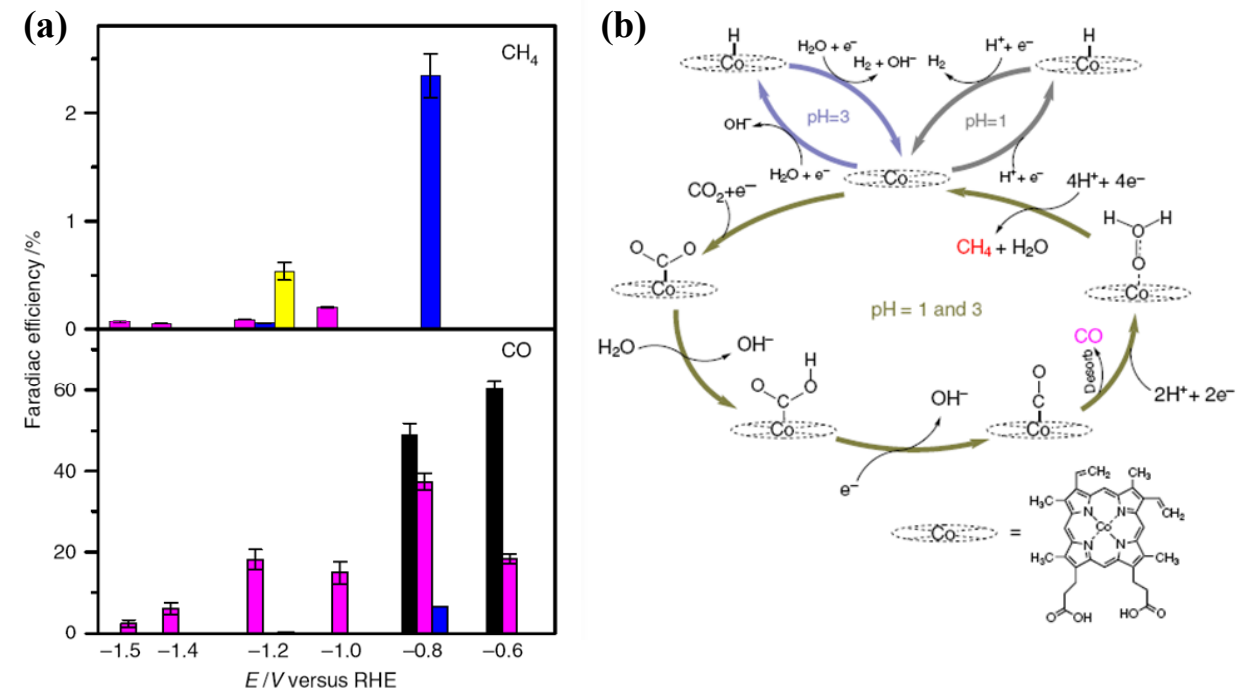

Fig. 13. (a) Faradaic efficiency of $\mathrm{CO}_{2}$ electroreduction to $\mathrm{CO}$ and $\mathrm{CH}_{4}$ in $0.1 \mathrm{~mol} \mathrm{~L}^{-1}$ perchlorate solution saturated with $\mathrm{CO}_{2}$. (yellow bars: $\mathrm{pH}=1, P_{\mathrm{CO} 2}$ $=1$ atm; blue bars: $\mathrm{pH}=1, P_{\mathrm{CO} 2}=10$ atm; magenta bars: $\mathrm{pH}=3, P_{\mathrm{CO} 2}=1$ atm; black bars: $\mathrm{pH}=3, P_{\mathrm{CO} 2}=10$ atm); (b) Proposed mechanistic pathway for the $\mathrm{CO}_{2} \mathrm{RR}$ on Co protoporphyrin. Reproduced with permission [90]. Copyright 2015, Springer Nature.

(ii) A suitable adjustment of local pH by employing electrolyte with appropriate bulk $\mathrm{pH}$ and buffer capacity helps to tune the product ratio leading to optimal Faradaic efficiency; (iii) To increase the selectivity of methane or other products that requires further electroreduction of $\mathrm{CO}$, a stronger binding of $\mathrm{CO}$ is essential [90].

\section{Conclusion and outlooks}

Recent advances on a variety of $\mathrm{M}-\mathrm{N}_{x}$ sites-containing transition metal-centered macrocyclic complexes, metal organic frameworks and $\mathrm{M}-\mathrm{N}_{X}$-doped carbon materials towards efficient $\mathrm{CO}_{2} \mathrm{RR}$ are summarized, including both experimental and theoretical studies. Unequivocally, these atomically dispersed metal nitrogen sites constituted of earth abundant elements with maximum atom-utilization efficiency exhibit great potential as promising alternatives for well-performed metal cata- 
(a)

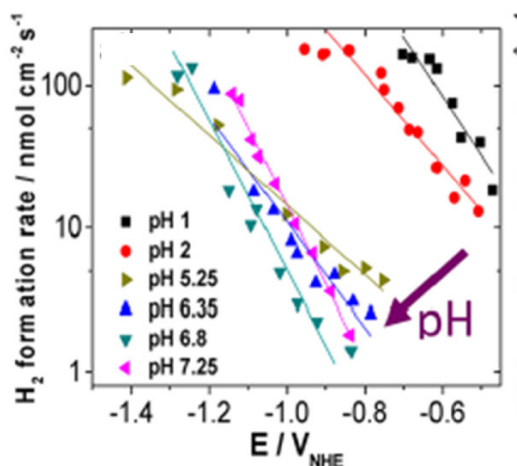

(b)

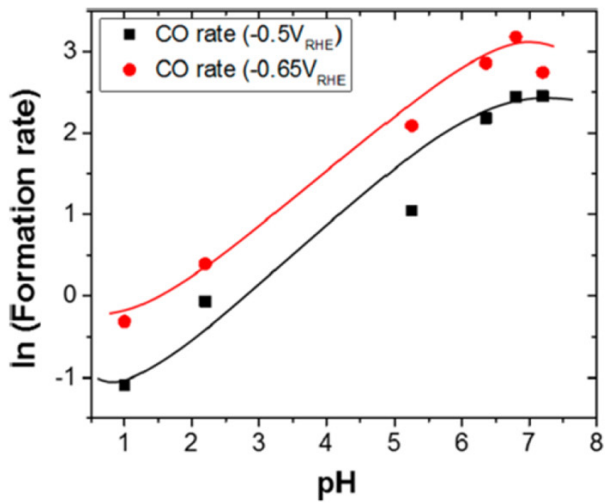

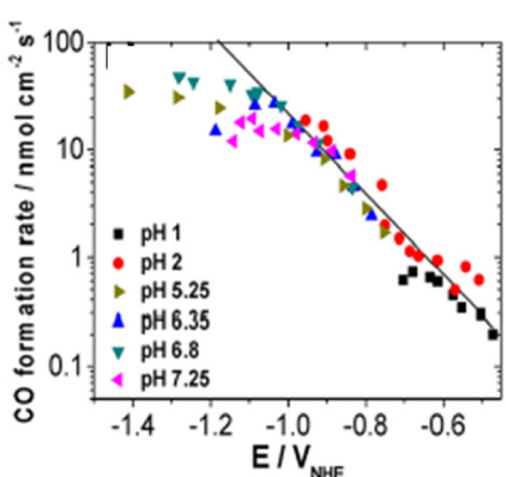

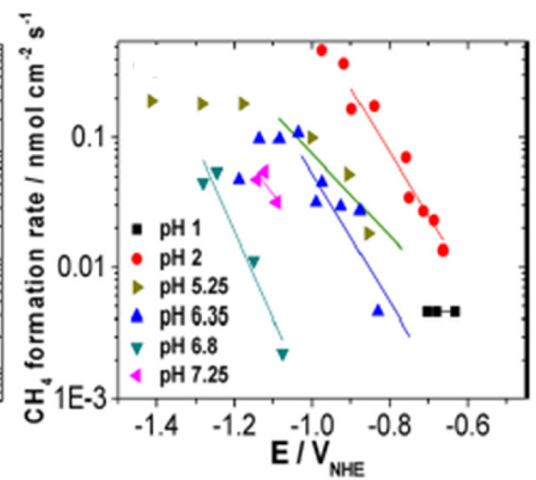

(c)

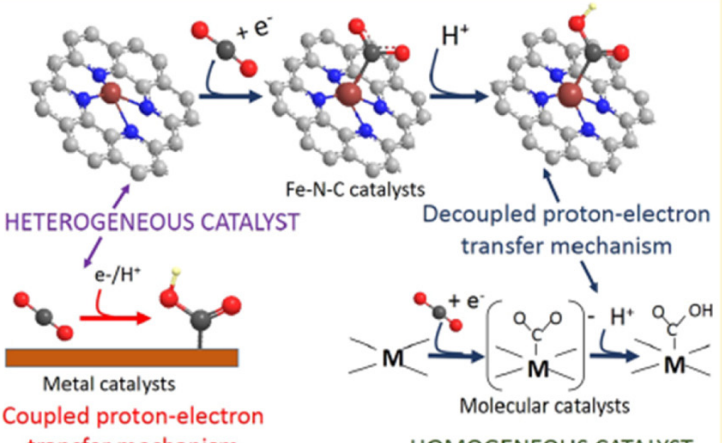

HOMOGENEOUS CATALYST

Fig. 14. (a) Formation rate for $\mathrm{H}_{2}, \mathrm{CO}$, and $\mathrm{CH}_{4}$ in different $\mathrm{CO}_{2}$-saturated electrolytes, black: $0.1 \mathrm{~mol} \mathrm{~L}^{-1} \mathrm{HClO}_{4}$; red: 0.1 mol L-1 $\mathrm{H}_{3} \mathrm{PO}_{4}$ - $\mathrm{K}_{3} \mathrm{PO}_{4}$; dark yellow: $0.1 \mathrm{~mol} \mathrm{~L}^{-1} \mathrm{KH}_{2} \mathrm{PO}_{4}$; blue: $0.1 \mathrm{~mol} \mathrm{~L}^{-1} \mathrm{KH}_{2} \mathrm{PO}_{4}-\mathrm{K}_{2} \mathrm{HPO}_{4}$; cyan: 0.1 mol L-1 $\mathrm{KHCO}_{3}$; pink: $0.3 \mathrm{~mol} \mathrm{~L} \mathrm{KHCO}_{3}$; (b) pH dependence of CO formation rate at a constant potential on the RHE scale, the shape of which resembles that expected for a DEPT reduction; (c) Diagram of the proposed catalytic cycle of $\mathrm{CO}_{2} \mathrm{RR}$ on Fe-N-C catalysts and metal-nitrogen molecular catalysts in a DEPT mechanism in comparison with the coupled proton-electron transfer mechanism prevailing in heterogeneous catalysis [91]. Reproduced with permission [91]. Copyright 2018, American Chemistry Society.

lysts $(\mathrm{Au}, \mathrm{Ag}, \mathrm{Cu}, \mathrm{Pd}$, etc.). Despite of the encouraging progress, the catalytic performance still needs to be optimized to meet the industrial requirements, and studies on unveiling the intricate reaction mechanisms are highly required for the exploration of optimal catalysts and reaction conditions. To be specific, high current density and stability are essential requirements for future application of $\mathrm{CO}_{2} \mathrm{RR}$, thus active sites should hold considerable turnover frequency and competitive HER should be inhibited at higher potentials in order to achieve a high performance and stability towards $\mathrm{CO}_{2} \mathrm{RR}$.

Though combined with conductive substrates contributes to the improved activity and selectivity towards $\mathrm{CO}_{2} \mathrm{RR}$ on $\mathrm{M}-\mathrm{N}_{x}$-containing macrocyclic complexes and MOF materials, poor conductivity which leads to limited electro-active sites still remains the main challenge. In contrast, carbon-based metal-nitrogen materials derived from pyrolysis of $\mathrm{N}-, \mathrm{C}-$ and transition metal-containing precursors endow excellent conductivity with improved charge/electron transfer capability. However, unlike macrocyclic complexes or MOF materials with precise active site structures, there are several functionalities (i.e., multiple $\mathrm{N}$ configurations and various metal nitrogen coordination states) in carbon-based metal-nitrogen catalysts, making it difficult to extract the structure-activity relationship. Therefore, careful control of synthetic strategies for structural uniformity of active sites, advanced in situ/operando characterization methods and profound theoretical simulations are the key for understanding the role of each functionality. As illustrated above, $\mathrm{CO}$ and formate are major products on carbon-based $\mathrm{M}-\mathrm{N}_{X}$ sites with few studies showing hydrocarbon or oxygenates as reduction products. Novel catalytic systems concerning $\mathrm{M}-\mathrm{N}_{x}$ active sites that can effectively reduce $\mathrm{CO}_{2}$ into more valuable products involving multiple proton/electron transfers still remain challenging. In addition to the intrinsic nature of active sites, a suitable adjustment of reaction conditions $(\mathrm{pH}$, buffer capacity, pressure, and set-up configurations) contributes to a higher selectivity to a certain product, and a deep understanding of the $\mathrm{CO}_{2} \mathrm{RR}$ mechanism provides inductive guidance for optimized catalytic processes in return. In brief, highly efficient, robust and cost-effective $\mathrm{M}-\mathrm{N}_{x}$ sites manifest great potential in promoting the industrial application of $\mathrm{CO}_{2} \mathrm{RR}$.

\section{References}

[1] M. Mikkelsen, M. Jørgensen, F. C. Krebs, Energy Environ. Sci., 2010, 3, 43-81.

[2] E. V. Kondratenko, G. Mul, J. Baltrusaitis, G. O. Larrazábal, J. Pérez-Ramírez, Energy Environ. Sci, 2013, 6, 3112-3135.

[3] M. Bui, C. S. Adjiman, A. Bardow, E. J. Anthony, A. Boston, S. Brown, P. S. Fennell, S. Fuss, A. Galindo, L. A. Hackett, J. P. Hallett, H. J. Herzog, G. Jackson, J. Kemper, S. Krevor, G. C. Maitland, M. Matuszewski, I. S. Metcalfe, C. Petit, G. Puxty, J. Reimer, D. M. 


\section{Graphical Abstract}

Chin. J. Catal., 2019, 40: 23-37 doi: 10.1016/S1872-2067(18)63161-4

\section{Transition metal-nitrogen sites for electrochemical carbon dioxide reduction reaction}

Chengcheng Yan, Long Lin, Guoxiong Wang *, Xinhe Bao*

Dalian Institute of Chemical Physics, Chinese Academy of Sciences; University of Chinese Academy of Sciences

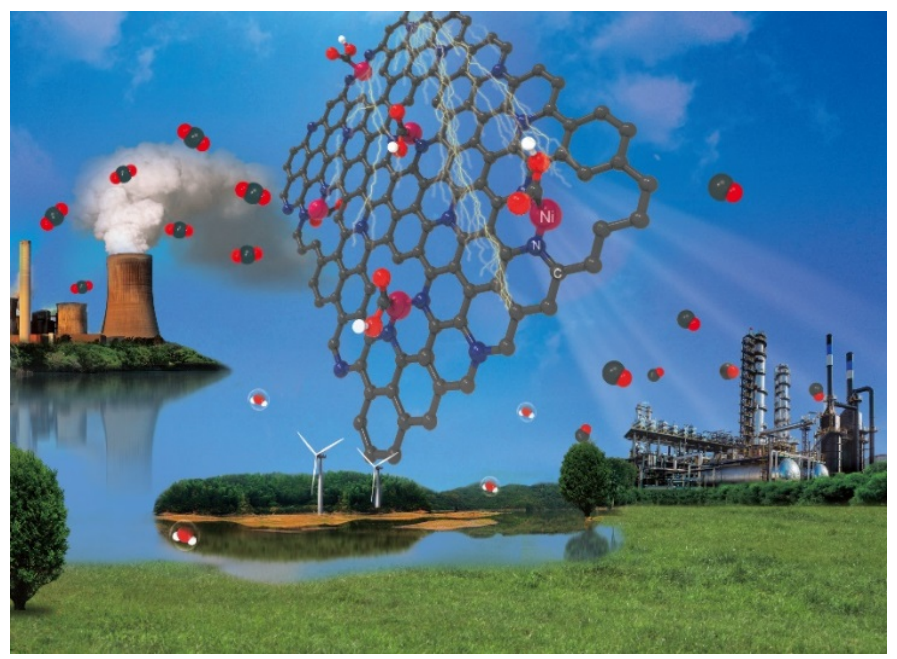

Metal-nitrogen sites constituted of earth abundant elements with maximum atom-utilization efficiency have emerged as promising catalysts for electrochemical $\mathrm{CO}_{2}$ reduction reaction.

Reiner, E. S. Rubin, S. A. Scott, N. Shah, B. Smit, J. P. M. Trusler, P. Webley, J. Wilcox, N. MacDowell, Energy Environ. Sci., 2018, 11, $1062-1176$.

[4] G. Yang, Z. P. Yu, J. Zhang, Z. X. Liang, Chin. J. Catal., 2018, 39, 914-919

[5] B. Khezri, A. C. Fisher, M. Pumera, J. Mater. Chem. A, 2017, 5, 8230-8246.

[6] L. Zhang, Z. J. Zhao, J. Gong, Angew. Chem. Int. Ed., 2017, 56, 11326-11353.

[7] D. D. Zhu, J. L. Liu, S. Z. Qiao, Adv. Mater., 2016, 28, 3423-3452.

[8] D. Gao, F. Cai, G. Wang, X. Bao, Curr. Opin. Green Sustainable Chem., 2017, 3, 39-44.

[9] Q. Lu, J. Rosen, Y. Zhou, G. S. Hutchings, Y. C. Kimmel, J. G. G. Chen, F. Jiao, Nat. Commun., 2014, 5, 3242-3247.

[10] Y. Chen, C. W. Li, M. W. Kanan, J. Am. Chem. Soc., 2012, 134, 19969-19972.

[11] A. S. Varela, N. Ranjbar Sahraie, J. Steinberg, W. Ju, H. S. Oh, P. Strasser, Angew. Chem. Int. Ed., 2015, 54, 10758-10762.

[12] J. Hao, W. Shi, Chin. J. Catal., 2018, 39, 1157-1166.

[13] Y. Hori, Electrochemical $\mathrm{CO}_{2}$ Reduction on Metal Electrodes, Springer, New York, 2008.

[14] J. Rosen, G. S. Hutchings, Q. Lu, R. V. Forest, A. Moore, F. Jiao, ACS Catal., 2015, 5, 4586-4591.

[15] D. H. Won, H. Shin, J. Koh, J. Chung, H. S. Lee, H. Kim, S. I. Woo, Angew. Chem. Int. Ed., 2016, 55, 9297-9300.

[16] Z. Yin, D. Gao, S. Yao, B. Zhao, F. Cai, L. Lin, P. Tang, P. Zhai, G. Wang, D. Ma, X. Bao, Nano Energy, 2016, 27, 35-43.

[17] W. L. Zhu, R. Michalsky, O. Metin, H. F. Lv, S. J. Guo, C. J. Wright, X. L.
Sun, A. A. Peterson, S. H. Sun, J. Am. Chem. Soc., 2013, 135, 16833-16836.

[18] D. Gao, Y. Zhang, Z. Zhou, F. Cai, X. Zhao, W. Huang, Y. Li, J. Zhu, P. Liu, F. Yang, G. Wang, X. Bao, J. Am. Chem. Soc., 2017, 139, 5652-5655.

[19] F. Li, D. R. MacFarlane, J. Zhang, Nanoscale, 2018, 10, 6235-6260.

[20] F. Guan, X. M. Zhang, Y. F. Song, Y. J. Zhou, G. X. Wang, X. H. Bao, Chin. J. Catal., 2018, 37, 1484-1492.

[21] W. Zhang, Y. Hu, L. Ma, G. Zhu, Y. Wang, X. Xue, R. Chen, S. Yang, Z. Jin, Adv. Sci., 2018, 5, 1700275.

[22] D. Gao, H. Zhou, J. Wang, S. Miao, F. Yang, G. Wang, J. Wang, X. Bao, J. Am. Chem. Soc., 2015, 137, 4288-4291.

[23] J. W. Vickers, D. Alfonso, D. R. Kauffman, Energy Technol., 2017, 5, 775-795.

[24] B. H. Zhang, J. T. Zhang, J. Energy Chem., 2017, 26, 1050-1066.

[25] G. F. Manbeck, E. Fujita, J. Porphyrins Phthalocyanines, 2015, 19, $45-64$.

[26] C. A. Downes, S. C. Marinescu, ChemSusChem, 2017, 10, 4374-4392.

[27] V. A. Sofia, J. Wen, S. Peter, Adv. Energy Mater., DOI: doi:10.1002/aenm.201703614.

[28] M. Lefèvre, E. Proietti, F. Jaouen, J.-P. Dodelet, Science, 2009, 324, 71-74.

[29] A. Zitolo, V. Goellner, V. Armel, M. T. Sougrati, T. Mineva, L. Stievano, E. Fonda, F. Jaouen, Nat. Mater., 2015, 14, 937-942.

[30] A. A. Gewirth, J. A. Varnell, A. M. DiAscro, Chem. Rev., 2018, 118, 2313-2339.

[31] C. Yan, H. Li, Y. Ye, H. Wu, F. Cai, R. Si, J. Xiao, S. Miao, S. Xie, F. Yang, Y. Li, G. Wang, X. Bao, Energy Environ. Sci., 2018, 11, 1204-1210. 
[32] Y. Ye, F. Cai, H. Li, H. Wu, G. Wang, Y. Li, S. Miao, S. Xie, R. Si, J. Wang, X. Bao, Nano Energy, 2017, 38, 281-289.

[33] X. M. Hu, H. H. Hval, E. T. Bjerglund, K. J. Dalgaard, M. R. Madsen, M. M. Pohl, E. Welter, P. Lamagni, K. B. Buhl, M. Bremholm, M. Beller, S. U. Pedersen, T. Skrydstrup, K. Daasbjerg, ACS Catal., 2018, 8, 6255-6264.

[34] N. Furuya, K. Matsui, J. Electroanal. Chem., 1989, 271, 181-191.

[35] N. Furuya, S. Koide, Electrochim. Acta, 1991, 36, 1309-1313.

[36] Y. Wu, J. Jiang, Z. Weng, M. Wang, D. L. J. Broere, Y. Zhong, G. W. Brudvig, Z. Feng, H. Wang, ACS Cent. Sci., 2017, 3, 847-852.

[37] J. J. Walsh, C. L. Smith, G. Neri, G. F. S. Whitehead, C. M. Robertson, A. J. Cowan, Faraday Discuss., 2015, 183, 147-160.

[38] A. Maurin, M. Robert, Chem. Commun., 2016, 52, 12084-12087.

[39] C. Costentin, S. Drouet, M. Robert, J. M. Saveant, Science, 2012, 338, 90-94.

[40] E. A. Mohamed, Z. N. Zahran, Y. Naruta, Chem. Mater., 2017, 29, 7140-7150.

[41] N. Morlanés, K. Takanabe, V. Rodionov, ACS Catal., 2016, 6, 3092-3095.

[42] X. Zhang, Z. Wu, X. Zhang, L. Li, Y. Li, H. Xu, X. Li, X. Yu, Z. Zhang, Y. Liang, H. Wang, Nat. Commun., 2017, 8, 14675-14682.

[43] N. Han, Y. Wang, L. Ma, J. Wen, J. Li, H. Zheng, K. Nie, X. Wang, F. Zhao, Y. Li, J. Fan, J. Zhong, T. Wu, D. J. Miller, J. Lu, S. T. Lee, Y. Li, Chem, 2017, 3, 652-664.

[44] C. Costentin, M. Robert, J.-M. Saveant, A. Tatin, Proc. Natl. Acad. Sci. U. S. A., 2015, 112, 6882-6886.

[45] I. M. B. Nielsen, K. Leung, J. Phys. Chem. A, 2010, 114, 10166-10173.

[46] K. Leung, I. M. B. Nielsen, N. Sai, C. Medforth, J. A. Shelnutt, J. Phys. Chem. A, 2010, 114, 10174-10184.

[47] Z. Weng, Y. Wu, M. Wang, J. Jiang, K. Yang, S. Huo, X. F. Wang, Q. Ma, G. W. Brudvig, V. S. Batista, Y. Liang, Z. Feng, H. Wang, Nat. Commun., 2018, 9, 415-423.

[48] X. M. Hu, M. H. Ronne, S. U. Pedersen, T. Skrydstrup, K. Daasbjerg, Angew. Chem. Int. Ed., 2017, 56, 6468-6472.

[49] A. R. Guadalupe, D. A. Usifer, K. T. Potts, H. C. Hurrell, A. E. Mogstad, H. D. Abruna, J. Am. Chem. Soc., 1988, 110, 3462-3466.

[50] B. L. Chen, S. C. Xiang, G. D. Qian, Acc. Chem. Res., 2010, 43, 1115-1124.

[51] J. Lee, O. K. Farha, J. Roberts, K. A. Scheidt, S. T. Nguyen, J. T. Hupp, Chem. Soc. Rev., 2009, 38, 1450-1459.

[52] H. Zhang, J. Nai, L. Yu, X. W. Lou, Joule, 2017, 1, 77-107.

[53] C. A. Downes, S. C. Marinescu, ChemSusChem, 2017, 10, 4374-4392.

[54] I. Hod, M. D. Sampson, P. Deria, C. P. Kubiak, O. K. Farha, J. T. Hupp, ACS Catal., 2015, 5, 6302-6309.

[55] J. Albo, D. Vallejo, G. Beobide, O. Castillo, P. Castaño, A. Irabien, ChemSusChem, 2017, 10, 1100-1109.

[56] N. Kornienko, Y. Zhao, C. S. Kley, C. Zhu, D. Kim, S. Lin, C. J. Chang, O. M. Yaghi, P. Yang, J. Am. Chem. Soc., 2015, 137, 14129-14135.

[57] L. Ye, J. Liu, Y. Gao, C. Gong, M. Addicoat, T. Heine, C. Wöll, L. Sun, J. Mater. Chem. A, 2016, 4, 15320-15326.

[58] Y. Wang, P. Hou, Z. Wang, P. Kang, ChemPhysChem, 2017, 18, 3142-3147.

[59] X. Jiang, H. Li, J. Xiao, D. Gao, R. Si, F. Yang, Y. Li, G. Wang, X. Bao, Nano Energy, 2018, 52, 345-350.

[60] M. Sadakiyo, T. Yamada, H. Kitagawa, J. Am. Chem. Soc., 2009, 131, 9906-9907.

[61] Z. Zhou, N. N. Chen, Q. Luo, L. Y. Jia, J. Wang, J. Q. Tao, J. Mol. Struct., 2017, 1136, 107-111.

[62] Y. J. Li, S. H. Zheng, X. Liu, P. Li, L. Sun, R. X. Yang, S. Wang, Z. S. Wu, X. H. Bao, W. Q. Deng, Angew. Chem. Int. Ed., 2018, 57, 7992-7996.
[63] R. Hinogami, S. Yotsuhashi, M. Deguchi, Y. Zenitani, H. Hashiba, Y. Yamada, ECS Electrochem. Lett., 2012, 1, H17-H19.

[64] R. Senthil Kumar, S. Senthil Kumar, M. Anbu Kulandainathan, Electrochem. Commun., 2012, 25, 70-73.

[65] S. Lin, C. S. Diercks, Y. B. Zhang, N. Kornienko, E. M. Nichols, Y. Zhao, A. R. Paris, D. Kim, P. Yang, O. M. Yaghi, C. J. Chang, Science, 2015, 349, 1208-1213.

[66] C. Z. Zhu, H. Li, S. F. Fu, D. Du, Y. H. Lin, Chem. Soc. Rev., 2016, 45, 517-531.

[67] M. X. Shen, C. T. Wei, K. L. Ai, L. H. Lu, Nano Res., 2017, 10, 1449-1470.

[68] J. Li, F. Jaouen, Curr. Opin. Electrochem., 2018, 9, 198-206.

[69] G. Wu, A. Santandreu, W. Kellogg, S. Gupta, O. Ogoke, H. G. Zhang, H. L. Wang, L. M. Dai, Nano Energy, 2016, 29, 83-110.

[70] P. Yin, T. Yao, Y. Wu, L. Zheng, Y. Lin, W. Liu, H. Ju, J. Zhu, X. Hong, Z. Deng, G. Zhou, S. Wei, Y. Li, Angew. Chem. Int. Ed., 2016, 55, 10800-10805.

[71] Y. Cheng, S. Zhao, B. Johannessen, J. P. Veder, M. Saunders, M. R. Rowles, M. Cheng, C. Liu, M. F. Chisholm, R. De Marco, H. M. Cheng, S.-Z. Yang, S. P. Jiang, Adv. Mater., 2018, 30, 1706287.

[72] Y. Chen, S. Ji, Y. Wang, J. Dong, W. Chen, Z. Li, R. Shen, L. Zheng, Z. Zhuang, D. Wang, Y. Li, Angew. Chem. Int. Ed., 2017, 56, 6937-6941.

[73] X. Wang, Z. Chen, X. Zhao, T. Yao, W. Chen, R. You, C. Zhao, G. Wu, J. Wang, W. Huang, J. Yang, X. Hong, S. Wei, Y. Wu, Y. Li, Angew. Chem. Int. Ed., 2018, 57, 1944-1948.

[74] T. N. Huan, N. Ranjbar, G. Rousse, M. Sougrati, A. Zitolo, V. Mougel, F. Jaouen, M. Fontecave, ACS Catal., 2017, 7, 1520-1525.

[75] C. Yan, Y. Ye, L. Lin, H. Wu, Q. Jiang, G. Wang, X. Bao, Catal. Today, 2018, DOI: https://doi.org/10.1016/j.cattod.2018.03.062.

[76] Y. Pan, R. Lin, Y. Chen, S. Liu, W. Zhu, X. Cao, W. Chen, K. Wu, W. C. Cheong, Y. Wang, L. Zheng, J. Luo, Y. Lin, Y. Liu, C. Liu, J. Li, Q. Lu, X. Chen, D. Wang, Q. Peng, C. Chen, Y. Li, J. Am. Chem. Soc., 2018, 140, 4218-4221.

[77] H. B. Yang, S. F. Hung, S. Liu, K. Yuan, S. Miao, L. Zhang, X. Huang, H. Y. Wang, W. Cai, R. Chen, J. Gao, X. Yang, W. Chen, Y. Huang, H. M. Chen, C. M. Li, T. Zhang, B. Liu, Nature Energy, 2018, 3, 140-147.

[78] C. Zhao, X. Dai, T. Yao, W. Chen, X. Wang, J. Wang, J. Yang, S. Wei, Y. Wu, Y. Li, J. Am. Chem. Soc., 2017, 139, 8078-8081.

[79] K. Jiang, S. Siahrostami, T. Zheng, Y. Hu, S. Hwang, E. Stavitski, Y. Peng, J. Dynes, M. Gangisetty, D. Su, K. Attenkofer, H. Wang, Energy Environ. Sci., 2018, 11, 893-903.

[80] X. Li, W. Bi, M. Chen, Y. Sun, H. Ju, W. Yan, J. Zhu, X. Wu, W. Chu, C. Wu, Y. Xie, J. Am. Chem. Soc., 2017, 139, 14889-14892.

[81] Z. Chen, K. Mou, S. Yao, L. Liu, ChemSusChem, 2018, 11, 2944-2952.

[82] Y. Zhao, J. Liang, C. Wang, J. Ma, G. G. Wallace, Adv. Energy Mater., 2018, 8, 1702524.

[83] M. Wu, K. Wang, M. Yi, Y. Tong, Y. Wang, S. Song, ACS Catal., 2017, 7, 6082-6088.

[84] W. Wei, H. Liang, K. Parvez, X. Zhuang, X. Feng, K. Müllen, Angew. Chem. Int. Ed., 2014, 53, 1570-1574.

[85] W. He, C. Jiang, J. Wang, L. Lu, Angew. Chem. Int. Ed., 2014, 53, 9503-9507.

[86] Y. Guo, H. Yang, X. Zhou, K. Liu, C. Zhang, Z. Zhou, C. Wang, W. Lin, J. Mater. Chem. A, 2017, 5, 24867-24873.

[87] W. Ju, A. Bagger, G. P. Hao, A. Sofia Varela, I. Sinev, V. Bon, B. Roldan Cuenya, S. Kaskel, J. Rossmeisl, P. Strasser, Nat. Commun., 2017, 8, 944-951.

[88] F. Pan, W. Deng, C. Justiniano, Y. Li, Appl. Catal. B, 2018, 226, 463-472.

[89] N. Sonoyama, M. Kirii, T. Sakata, Electrochem. Commun., 1999, 1, 
213-216.

[90] J. Shen, R. Kortlever, R. Kas, Y. Y. Birdja, O. Diaz-Morales, Y. Kwon, I. Ledezma-Yanez, K. J. P. Schouten, G. Mul, M. T. M. Koper, Nat. Commun., 2015, 6, 8177-8182.
[91] A. S. Varela, M. Kroschel, N. D. Leonard, W. Ju, J. Steinberg, A. Bagger, J. Rossmeisl, P. Strasser, ACS Energy Lett., 2018, 3, 812-817.

[92] J. Shen, M. J. Kolb, A. J. Göttle, M. T. M. Koper, J. Phys. Chem. C, 2016, 120, 15714-15721.

\title{
过渡金属-氮活性位点在二氧化碳电化学还原反应中的应用
}

\author{
阎程程 ${ }^{\mathrm{a}, \mathrm{b}}$ ，林 龙 $\mathrm{a}, \mathrm{b}$, 汪国雄 $\mathrm{a}^{\mathrm{a}, \mathrm{c}, *}$, 包信和 ${ }^{\mathrm{a}, \mathrm{c}, \text {, }}$ \\ a 中国科学院大连化学物理研究所催化基础国家重点实验室, 中国科学院纳米科学卓越创新中心, 辽宁大连 116023 \\ b中国科学院大学, 北京 100049 \\ ' 中国科学院大连化学物理研究所洁净能源国家实验室(筹), 辽宁大连 116023
}

\begin{abstract}
摘要: 大气中过高的 $\mathrm{CO}_{2}$ 浓度严重影响自然界的碳循环平衡, 对全球气候和生态环境提出了严峻挑战. 但同时 $\mathrm{CO}_{2}$ 作为一 种潜在的碳资源, 可通过催化转化生成高附加值的化学品. $\mathrm{CO}_{2}$ 电化学还原反应 $\left(\mathrm{CO}_{2} \mathrm{RR}\right)$ 可利用太阳能、风能等可再生能源 产生的电能将 $\mathrm{CO}_{2}$ 直接转化生成高附加值化学品和燃料, 有助于构建“碳中性”的能源循环利用网络, 具有极具潜力的应用 前景. 然而, 活化稳定的 $\mathrm{CO}_{2}$ 分子需克服一定的过电势, 且由于反应在水相中进行, $\mathrm{CO}_{2} \mathrm{RR}$ 与析氢反应互相竞争, 因此开发 高效、廉价、稳定的催化剂一直是 $\mathrm{CO}_{2} \mathrm{RR}$ 研究的难点. 研究表明, 含有金属-氮 $\left(\mathrm{M}-\mathrm{N}_{x}\right)$ 活性位的催化材料如卟啉、酞菁等大 环配合物、金属有机骨架材料以及通过热解法制备的金属-氮-碳( M-N-C)材料具有优异的 $\mathrm{CO}_{2} \mathrm{RR}$ 性能. 本文从实验和理论 两方面综述了近年来该类材料领域的相关进展, 重点介绍了金属位点种类、配体结构、载体选择对催化剂本征活性的影响, 并讨论了反应条件优化对 $\mathrm{CO}_{2} \mathrm{RR}$ 性能提升的作用. 结合原位表征和理论计算结果探讨了含 $\mathrm{M}-\mathrm{N}_{x}$ 材料反应条件下活性位的 结构及反应路径, 为合理设计和优化 $\mathrm{CO}_{2} \mathrm{RR}$ 催化剂体系提供了新思路.
\end{abstract}

关键词: 二氧化碳电化学还原反应; 金属-氮位点; 含金属-氮位点的大环化合物; 金属有机骨架; 沸石咪唑骨架; 金属-氮 掺杂碳材料

收稿日期: 2018-09-04. 接受日期: 2018-09-19. 出版日期: 2019-01-05.

*通讯联系人. 电话: (0411)84686637; 传真: (0411)84694447; 电子信箱: wanggx@dicp.ac.cn

\#通讯联系人. 电子信箱: xhbao@dicp.ac.cn

基金来源：国家重点研发计划(2017YFA0700102); 国家自然科学基金(21573222，91545202); 大连杰出青年人才计划(2017RJ03); 中国科学院大连化学物理研究所DMTO项目(DICP DMTO201702); 中国科学院战略性先导科技专项(XDB17020200); 中国科学 院青年创新促进会(2015145).

本文的电子版全文由Elsevier出版社在ScienceDirect上出版(http://www.sciencedirect.com/science/journal/18722067). 